\title{
Reproductive Selection Bias
}

Lauren R. Roth

Follow this and additional works at: https://scholarlycommons.law.case.edu/healthmatrix

Part of the Health Law and Policy Commons

\section{Recommended Citation}

Lauren R. Roth, Reproductive Selection Bias, 27 Health Matrix 263 (2017)

Available at: https://scholarlycommons.law.case.edu/healthmatrix/vol27/iss1/11

This Article is brought to you for free and open access by the Student Journals at Case Western Reserve University School of Law Scholarly Commons. It has been accepted for inclusion in Health Matrix: The Journal of Law-Medicine by an authorized administrator of Case Western Reserve University School of Law Scholarly Commons. 


\title{
Reproductive Selection Bias
}

\author{
Lauren R. Roth ${ }^{+}$ \\ New York University School of Law
}

\begin{abstract}
Decades after the advent of assisted reproductive technology ("ART") that allows prospective parents to deselect embryos with grave genetic illnesses - a procedure called preimplantation genetic diagnosis ("PGD")it remains a tool largely of upper-class whites. I argue that the time has come to focus on closing the access gap in this area of reproductive rights in spite of the current political climate. If reproductive liberty is tied to equality through access to medical procedures, scholars must finally answer the question of what equality requires in a system that permits the use of ARTs.

This Article shows how the current system of assisted reproduction already distinguishes between the "in" group and the "out" group. Section I explores the literature's focus on the use and growth of PGD for genetic selection unrelated to the prevention of genetic disease ("nontherapeutic PGD"), including the use of PGD for sex and other physical-trait selection. The scholarly overemphasis on tricky moral quandaries associated with the nontherapeutic use of PGD where liberty concerns are at the forefront impedes any proposed solutions to unequal access to using PGD to prevent inherited illnesses.

Section II similarly explores how existing jurisprudence ignores the role of income inequality and broader social concerns when deciding disputes related to PGD. Courts address any negative implications of their decisions for the children of those who are able to afford PGD but fail to address the impact of their decisions on the children of those who cannot afford PGD.

Finally, I discuss in Section III how the combined effect of the Affordable Care Act ("ACA") antidiscrimination and essential health benefit mandates is to focus on ensuring equality of access to healthcare, particularly for underserved populations. While few scholars would argue today that reproductive technology is likely to be included among the essential health benefits the ACA requires, if the statute remains intact, it is one more example of the troublesome class distinctions that currently divide this country into "haves" and "have nots." The reverse eugenics of therapeutic
\end{abstract}

$\dagger \quad$ Associate Director of Lawyering Program and Acting Assistant Professor, New York University School of Law. Ph.D. 2014, Columbia University; J.D. 2004, Harvard Law School; B.A. 2001, The George Washington University. I am grateful for the helpful comments provided by Adam Kolber, Sylvia Law, Radhika Rao, Christopher Robertson, and participants in the 39th Annual Health Law Professors Conference and the Lawyering Scholarship Colloquium at NYU. Thanks also to Megan Howe, Dana Wellesly-Stein, and Whitney Wadman for very helpful research assistance. 
PGD privileges wealthy whites above other races and classes, and it exacerbates race and class distinctions.

\section{Contents}

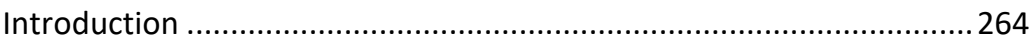

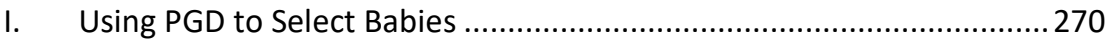

A. The Tension Between Liberty and Equality ..................................2272

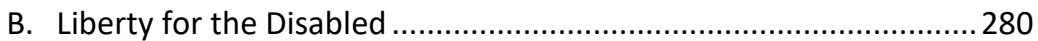

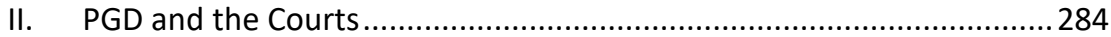

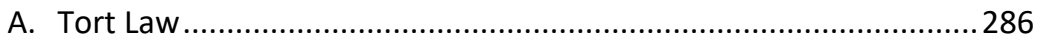

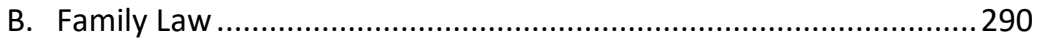

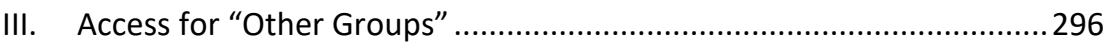

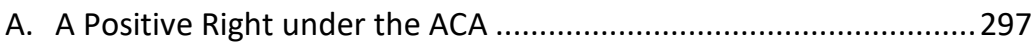

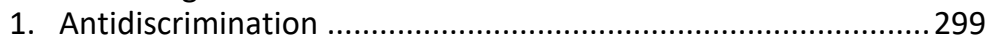

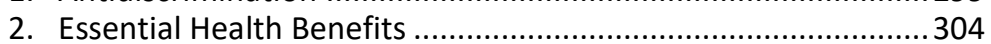

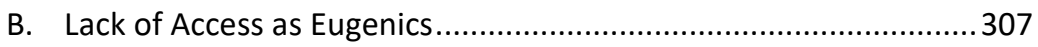

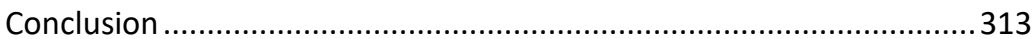

\section{Introduction}

There are many goods and services that the poor cannot afford to buy. From decent housing to luxury cars, from new clothes to vacations at the beach, their unmet needs and wants are extensive. Through direct subsidies and indirect tax credits and deductions, society tries to fill some of these unmet needs. Grudgingly or not, completely or not, government programs tackle needs including housing, food, and healthcare.

Given that few would argue that the government is fully meeting these basic needs, it is unsurprising that there is currently no public funding for advanced fertility treatments for the poor. But this is a case where a negative right against government interference in family planning should become a positive right to funding to create "healthy" children. ${ }^{1}$ An example can help demonstrate why we should be funding fertility treatments instead of-or, ideally, in addition to-investing more in housing or education.

Two couples, ${ }^{2}$ the Bakers and the Smiths, are looking to conceive a child and have an observed family history of Huntington's disease. At the start,

1. Dorothy E. Roberts, Race and the New Reproduction, 47 HASTINGS L.J. 935, 946 (1996) [hereinafter Roberts I] ("Reproduction is special. Government policy concerning reproduction has tremendous power to affect the status of entire groups of people.... It is precisely the connection between reproduction and human dignity that makes a system of procreative liberty that privileges the wealthy and powerful particularly disturbing.").

2. I use two heterosexual couples in my example here. The discussion applies equally to homosexual couples attempting to use the sperm or eggs of one member with a genetic predisposition to an illness or chromosome abnormality. 
the disease is as prevalent among wealthy families and among poor families. Without any additional action, they face the same risk of passing the gene for the disease to their offspring. Unfortunately, genetic testing reveals that Mother Baker carries the gene and will, absent medical intervention, face a fifty-percent risk of passing that gene and the disease itself along to her offspring because Huntington's is a dominant gene. ${ }^{3}$ Mother Smith also carries the Huntington's gene and bears the same risk of passing along the gene to her children, but she is poor and, therefore, less likely to engage in genetic testing and discover this fact. ${ }^{4}$

Even assuming that both families know enough about their history and about the disease to have genetic testing done, ${ }^{5}$ they face very different paths forward in conceiving biological children. Although Mother Baker has no known fertility problems, she can use in vitro fertilization ("IVF") to produce embryos that will then undergo preimplantation genetic diagnosis ("PGD"). With PGD, a single cell (typically) is taken from each embryo in a biopsy and tested to see if its DNA contains the gene for the disease. ${ }^{6} \mathrm{By}$ selecting embryos without the gene-absent the small risk of human error or other reasons for mistakenly implanting an embryo that contains the gene for the disease-the Baker family now has a healthy baby with no risk of developing Huntington's disease.

3. For a recessive gene such as cystic fibrosis (CF), a child must inherit two copies of the gene (one from each parent who is a carrier of the gene) to manifest the disease. The odds of two CF carriers producing a baby with the disease is $25 \%$. There is a $50 \%$ chance the child will be a CF carrier with one copy of the gene. $C F$ Genetics: The Basics, CYSTIC FIBROSIS Found., http://www.cff.org/What-isCF/Genetics/CF-Genetics-Basics (last visited Apr. 1, 2017). The calculation is more complicated for genes such as BRCA1 and BRCA2 that increase the risk of several cancers, including breast and ovarian cancer, but do not manifest in the diseases with complete certainty. See BRCA1 and BRCA2: Cancer Risk and Genetic Testing, NAT'L CANCER INST., http://www.cancer.gov/about-cancer/causesprevention/genetics/brca-fact-sheet (last visited Apr. 1, 2017).

4. See Drew Anne Scarantino, Would You Pay for Genetic Testing?, Forbes (June 13, 2013), http://www.forbes.com/sites/learnvest/2013/06/13/would-you-pay-forgenetic-testing/\#17489d9152b3; What is the Cost of Genetic Testing, And How Long Does it Take to get the Results?, U.S. NAT'L LIBR. MED., http://ghr.nlm.nih.gov/primer/testing/costresults (last visited July 12, 2016) ("The cost of genetic testing can range from under $\$ 100$ to more than $\$ 2,000$, depending on the nature and complexity of the test.").

5. See, e.g., Ruqaiijah Yearby, Breaking the Cycle of "Unequal Treatment" with Health Care Reform: Acknowledging and Addressing the Continuation of Racial Bias, 44 CONN. L. REV. 1281, 1296-1301 (2012) (discussing interpersonal racial bias and how it "leads to racial disparities in medical treatment").

6. See Preimplantation Genetic Diagnosis \& Screening, N.Y.U. LANGONE MED. CTR., http://nyulangone.org/locations/fertility-center/preimplantation-geneticdiagnosis-screening (last visited Apr. 1, 2017) ("Preimplantation genetic diagnosis can identify specific genes associated with conditions such as cystic fibrosis, hemophilia, Huntington's disease, Marfan syndrome, muscular dystrophy, thalassemia, Tay-Sachs disease, spinal muscular atrophy, and sickle cell anemia."). 
The Baker family has spent a lot of money to ensure that Baby Baker is healthy, though. ${ }^{7}$ For that price, the Bakers no longer have to worry about their children or their grandchildren inheriting the disease. They also save the money needed to treat the disease and care for family members with the disease. Although Mother Baker will one day live with Huntington's disease, future Baker generations will not, and they will have no reason to lobby for research into treatments for the disease, to donate to related charities, or even to walk in the annual event to show solidarity with others affected by the disease. The market for future treatments will be a little smaller by number and a lot less profitable, assuming that those most likely to pay for expensive new treatments will no longer have the disease. ${ }^{8}$

If, instead, all members of the two couples here are carriers of cystic fibrosis ("CF"), which allows two healthy carriers to each pass a recessive CF gene to a child to produce a child with CF, the Baker family can use IVF and PGD to nearly eliminate its risk of passing CF to its offspring. The Baker

7. See Marissa A. Mastroianni, Bridging the Gap Between the "Have" and the "HaveNots": The ACA Prohibits Insurance Coverage Discrimination Based Upon Infertility Status, 79 AlB. L. ReV. 151, 158 (2015-16) ("An average IVF cycle in the United States can cost between $\$ 10,000$ and $\$ 15,000$ with only a $25-30 \%$ live birth success rate. Therefore, many couples will need to undergo several IVF cycles to achieve their desired outcome." (footnotes omitted)). Note that these figures include only the cost of IVF and not the cost of laboratory work to engage in PGD, substantially underestimating the cost of the process. While a number of states require health insurance plans to cover infertility treatment, they do not discuss the use of IVF and PGD for genetic reasons rather than infertility. In addition, wanting to have more than one child results in completing the process multiple times. See State Laws Related to Insurance Coverage for Infertility Treatment, NAT'L Conf. St. LEgISLATURES (June $1, \quad$ 2014) http://www.ncsl.org/research/health/insurance-coverage-for-infertility-

laws.aspx ("15 states-Arkansas, California, Connecticut, Hawaii, Illinois, Louisiana, Maryland, Massachusetts, Montana, New Jersey, New York, Ohio, Rhode Island, Texas and West Virginia-have passed laws that require insurers to either cover or offer coverage for infertility diagnosis and treatment. Thirteen states have laws that require insurance companies to cover infertility treatment.").

8. See Judith F. Daar, ART and the Search for Perfectionism: On Selecting Gender, Genes, and Gametes, 9 J. GENDER RACE \& JUST. 241, 259-60 (2005) [hereinafter Daar I] ("If PGD has the effect of encouraging parents to avoid procreating children with identifiable genetic disorders, it is posited that individuals who do suffer from these gene-based diseases will face increased discrimination on three fronts. First, a public policy that favors ridding the human race of a disease that plagues fewer and fewer of our fellow citizens risks 'orphaning' the disease, that is, rarity makes the disease, and by fiat its host, an outcast in the scientific and health communities .... Affected individuals will have little hope of seeing a cure, unless public monies are expended on behalf of furthering research in the field. Second, individuals who are afflicted with a genetic disorder that was susceptible to detection by PGD will likely be part of a lower socioeconomic class . . . and thus will face further marginalization by society at large . . . . Finally, ... [i]f an attitude develops that 'certain diseases can and therefore should be avoided,' persons born with such diseases may be perceived as culpable for their own diminished health, further discrimination against the disabled." (footnotes omitted)). 
family removes itself from the CF population quickly and provides no attention or funding to the cause going forward.

The Smith family, on the other hand, faces a difficult choice. The couple is determined to have biological children but cannot afford the cost of IVF, let alone the cost of IVF and PGD. ${ }^{9}$ Depending on insurance and other resources, the Smith family can conceive naturally and then test the fetus for Huntington's disease via amniocentesis. Assuming the family can afford this procedure, however, any positive test result would require terminating the pregnancy if the family does not want to pass on the disease. For the Smith family, producing a child without the gene might entail several failed pregnancies.

If the Smith family conceives and does not test for the Huntington's gene using amniocentesis, then they have a fifty-percent chance of passing the gene to each of their children. Since the Baker family opted out of the disease, the Smith family now-or within a few generations, at least-faces a world in which the wealthy do not have the disease and therefore do not spend to research the disease and treatments or cures. Among the population that was previously equally at risk for developing Huntington's disease, wealthy people now have "healthy" babies who will never develop the disease, and poor people have "sick" babies who have a fifty percent chance of inheriting the disease. ${ }^{10}$

In this Article, I argue that there should be a positive right to the funding of fertility treatments for parents with genes that can reduce their children's life expectancy or greatly impair their quality of life. If, at the very moment of birth, poor children and wealthy children are not equal because money can buy different genetic coding for length and quality of life, then there is no hope of equality at any point thereafter. If there is no equality at this one moment, then there is no liberty for the poor children who start life with a stigma that the wealthy can avoid. While line drawing is always difficult and there is a slippery slope, a negative right should become a positive right when it is necessary to create all babies equal.

9. Dorothy E. Roberts, The Genetic Tie, 62 U. CHI. L. REV. 209, 244 (1995) [hereinafter Roberts II] ("The people in the United States most likely to be infertile are older, poorer, Black, and poorly educated. Most couples who use IVF services are white, highly educated, and affluent. New reproductive technologies are so popular in American culture not simply because of the value placed on the genetic tie, but because of the value placed on the white genetic tie." (footnotes omitted)).

10. See Judith Daar, Panel 2-Reproductive Healthcare Legislation: Where We've Been and Where We're Going, 23 ALB. L.J. SCI. \& TECH. 511, 517 (2013) ("There are also some more nuanced arguments about orphaning certain diseases. For example, if we were to use PGD to eliminate Down's Syndrome, then it's going to be the case that not everyone can access PGD because it is expensive and not covered by insurance. So you are going to have this sort of binary approach where people who are wealthier and can afford PGD will not have kids with these disabilities but people who cannot afford PGD are going to have children who do have these genetic anomalies."). 
Two decades after the advent of the technology that allows us to screen out certain genetic diseases - at a time when its use is growing-we stand at the precipice of a dramatic increase in social inequalities as a result. At this point, we all recognize the importance (politically, if not ethically) of reducing social inequality in this country. Scholars advocating for reproductive liberty, or procreative liberty, as it is frequently called, have focused on reproductive choice and allowing some to use assisted reproductive technologies ("ARTs"). ${ }^{11}$ Yet asserting that ARTs are morally justified and should be legally permitted does not address the disparity in utilization rates between classes and races. ${ }^{12}$

Scholars, particularly Dorothy Roberts and Radhika Rao, have sought to advance equality in reproductive liberty, but questioned at times whether ARTs should instead be prohibited for all and genetic parentage deemphasized. ${ }^{13}$ I assume here, given the popularity of ARTs among those who can afford to use them (largely wealthy whites), that it is unrealistic to ban or substantially limit their use in the case of preventing genetic diseases in offspring. If liberty is tied to equality, scholars must finally answer the question of what equality requires in a system that permits the use of ARTs.

I propose that we move beyond the current discussions of morality and legality of new ARTs because existing technology shows that we cannot achieve reproductive equality without a positive right to government funding. This Article details how the lack of funding for ARTs already distinguishes between the "in" group and the "out" group-the unfortunate other who lead supposedly lesser, wrongful lives in comparison to those with access to ARTs. The law can and should help close the gap

11. See Andrew B. Coan, Assisted Reproductive Equality: An Institutional Analysis, 60 CASE W. RES. L. REV. 1143, 1144-45 (noting that most scholars have focused on whether constitutional protection of procreative liberty should be extended to ARTs and "[i]f so, which ones, and in what circumstances").

12. Mastroianni, supra note 7, at 162 ('Secondly, the patient 'profile' for individuals seeking infertility treatment is worrisome, especially because the right to procreate is a fundamental right recognized by the United States Supreme Court. The statistics show a positive correlation of infertility treatment usage with higher household income and higher education levels. According to one study, '[t]here is an 11 percent chance that low-income women will pursue ART, while high-income women are almost twice as likely to do so.' Thus, a divide between the 'haves' and the 'have-nots' based upon these socioeconomic factors is suspect to the say the least." (footnotes omitted)). There is no reason to think that the utilization rates for PGD are any higher among those with lower incomes than for IVF alone. In fact, given the cost of PGD, there is reason to believe that the utilization rates for IVF and PGD show greater socioeconomic disparities.

13. Radhika Rao, Equal Liberty: Assisted Reproductive Technology and Reproductive Equality, 78 GEO. WASH. L. REV. 1457, 1478-79 (2008) (arguing that it would be constitutional to ban the use of ARTs for all); Roberts I, supra note 1, at 947-49 ("Black women in particular would be better served by a focus on the basic improvement of conditions that lead to infertility, such as occupational and environmental hazards, diseases, and complications following childbirth and abortion."). 
under the $A C A,{ }^{14}$ particularly given that reverse eugenics privileges the wealthy and disproportionately white above other races and classes. I use PGD here as a lens to focus on ARTs more generally.

Section I of this Article will explore the literature's focus on the use and growth of PGD for genetic selection unrelated to the prevention of genetic disease ("nontherapeutic PGD"), including the use of PGD for sex and other physical-trait selection. Given that most people cannot afford the more urgently needed therapeutic use of PGD (about which there are fewer moral and legal concerns), the scholarly emphasis on the nontherapeutic use of PGD and novel challenges to reproductive liberty is misplaced. In fact, the overemphasis on tricky moral quandaries associated with the nontherapeutic use of PGD, where liberty concerns are at the forefront, impedes any proposed solutions to unequal access to using PGD to prevent grave, inherited illnesses. I argue that liberty is intertwined with equity where it produces "sick" children who could otherwise be born "healthy." A negative right becomes a positive right to funding for ARTs where poor children will otherwise suffer illness and social stigma that is preventable before birth.

Section II explores how existing jurisprudence ignores the role of income inequality and broader social concerns in deciding disputes related to PGD. Courts have slowly begun to resolve the disputes that arise when the use of PGD for the prevention of genetic disease goes awry, including custody disputes over embryos. A growing body of literature addresses the use of a tort law claim for wrongful life when a doctor or lab's mistake results in the conception of a baby with a genetic disease that could have been prevented absent negligence. More enthralled with this tort theory than are the courts, scholars have largely overlooked the implications that any successful wrongful life claims would have for those without access to therapeutic PGD. In family law disputes over custody of embryos, the weight courts have placed on having a healthy, genetic child again advantages those who can afford therapeutic PGD and stigmatizes those who cannot.

I argue in Section III that equal access to PGD and to all ARTs is more important than ever because of the likelihood that key pieces of the ACA will be repealed. If Congress and the President repeal the ACA's individual mandate, it will make the popular provision that prevents insurance plans from rejecting individuals with pre-existing medical conditions or charging them higher premiums difficult to maintain as young, healthy consumers opt out of health insurance. ${ }^{15}$ The ACA's mandates can help bridge the gap

14. Health Care and Education and Reconciliation Act of 2010 (HCERA), Pub. L. No. 111-152, 124 Stat. 1029 (2010); Patient Protection and Affordable Care Act (PPACA), Pub. L. No. 111-148, 124 Stat. 119 (2010) (jointly "ACA").

15. See Margot Sanger-Katz, Why Keeping Only the Popular Parts of Obamacare Won't Work, N.Y. TIMES (Nov. 15, 2016), http://www.mobile.nytimes.com/2016/11/15/upshot/why-keeping-only-thepopular-parts-of-obamacare-wont-work.html?_r=0 (discussing inevitable cycle of increasing premiums and decreasing enrollment in insurance markets that 
between classes and between the healthy and the sick. Section 1557 of the ACA prohibits discrimination in health insurance on the basis of health status, race, and sex. ${ }^{16}$ In addition, the ACA requires the Secretary of Health and Human Services to "take into account the health care needs of diverse segments of the population, including women, children, persons with disabilities, and other groups" when defining essential health benefits ("EHBs"). ${ }^{17}$ The combined effect of these mandates is to focus on ensuring equality of access to healthcare for all, particularly underserved populations. Reproductive technology should be a key area in the discussion of how to define EHBs, and the illustration of therapeutic PGD demonstrates why. There is an administrative law solution that creates healthy children who society does not stigmatize because of their preventable genetic conditions, assuming the ACA-or at least its goalsremain intact.

\section{Using PGD to Select Babies}

Courts have broadly affirmed the right to procreate and the right to be free from government intervention into personal matters, including the bearing of a child (a negative right). ${ }^{18}$ Scholars have moved down the

prohibit discrimination against those with pre-existing conditions but do not have an individual mandate forcing the young and healthy to buy insurance).

16. PPACA $\S 1557$ (codified at 42 U.S.C. $\S 18116$ ) ("Except as otherwise provided for in this title ... an individual shall not, on the ground prohibited under title VI of the Civil Rights Act of 1964 (42 U.S.C. 2000d et seq.), title IX of the Education Amendments of 1972 (20 U.S.C. 1681 et seq.), the Age Discrimination Act of 1975 (42 U.S.C. 6101 et seq.), or section 504 of the Rehabilitation Act of 1973 (29 U.S.C. 794), be excluded from participation in, be denied the benefits of, or be subjected to discrimination under, any health program or activity, any part of which is receiving Federal financial assistance, including credits, subsidies, or contracts of insurance, or under any program or activity that is administered by an Executive Agency or any entity established under this title (or amendments).").

17. Id. at $\S 1302(\mathrm{~b})(4)(\mathrm{C})$ (codified at 42 U.S.C. $\S 18022(\mathrm{~b})(4)(\mathrm{C})$ ).

18. See Lawrence v. Texas, 539 U.S. 558, 578 (2003) (overturning Bowers v. Hardwick and finding a due process violation where a statute prohibited same-sex sexual acts because " $[t]$ he Texas statute furthers no legitimate state interest which can justify its intrusion into the personal and private life of the individual"); Planned Parenthood of Se. Pa. v. Casey, 505 U.S. 833, 896 (1992) (striking down requirement that women seeking abortions certify that they have notified the father of the fetus prior to obtaining an abortion because of the "far greater impact on the mother's liberty than on the father's" and noting that "the State has touched not only upon the private sphere of the family but upon the very bodily integrity of the pregnant woman"); Roe v. Wade, 410 U.S. 113, 163 (1973) (striking down under the Due Process Clause of the Fourteenth Amendment a statute criminalizing abortion but noting that the State's interests in regulating abortion becomes "compelling" at viability); Eisenstadt v. Baird, 405 U.S. 438, 453 (1972) (striking down Massachusetts ban on the distribution of contraceptives to unmarried individuals under the Equal Protection Clause of the Fourteenth Amendment because "[i]f the right of privacy means anything, it is the right of the individual, married or single, to be free from unwarranted governmental intrusion 
slippery slope to test this right in the face of new technologies that permit or will soon permit would-be parents to select offspring with desired traits and even manipulate the DNA of embryos to design their own children. ${ }^{19}$ If couples can use PGD to avoid passing certain genes on to their children, ${ }^{20} \mathrm{a}$ so-called "procreative liberty" may allow parents to use PGD to choose their children's sex, physical appearance, or even sexual orientation simply as a matter of preference. ${ }^{21}$ John Robertson argues that income disparities, which make this new technology inaccessible to some, should not interfere with the right of others to procreate using these methods. ${ }^{22}$ As he has made clear for decades in his research and states in Children of Choice: Freedom and the New Reproductive Technologies:

One can decry the disparities that exist and urge that society correct distributive inequities, however, without denying all persons the right to make these choices. In the end, the need for social justice is not a compelling reason for limiting the procreative choice of those who can pay. ${ }^{23}$

Over the years, scholars including Dorothy Roberts and Radhika Rao have pushed to bring equality forward in the debate about ARTs. ${ }^{24}$ Some

into matters so fundamentally affecting a person as the decision whether to bear or beget a child"); Griswold v. Connecticut, 381 U.S. 479, 485 (1965) (citing the constitutional "zone of privacy" surrounding the marital relationship when refusing to enforce a statute prohibiting the use of contraceptives).

19. John A. Robertson, Procreative Liberty in the Era of Genomics, 29 AM. J.L. \& MED. 439, 442 (2003) [hereinafter Robertson I] ("A central dilemma is that accepting any instance of genetic selection in principle implies accepting most other instances of selection as well. But some uses seem much more questionable and less beneficial than the one initially accepted. Can acceptable lines be drawn, or is it better, as some would argue, to permit little, if any, genetic selection to occur?").

20. John A. Robertson, Children of Choice: Freedom and the New Reproductive TECHNOLOGIES 162 (1994) [hereinafter Robertson II] ("Assuming safety and efficacy, the main objections to therapeutic interventions on embryos are effects on the gene pool and later generations and slippery slope fears that it will lead to more dangerous interventions. However, neither harm is sufficiently weighty to deny parents this path to healthy offspring.").

21. See id. at 4 ("To deny procreative choice is to deny or impose a crucial self-defining experience, thus denying persons respect and dignity at the most basic level.").

22. Id. at 225-26 ("Yet it does not follow that society's failure to assure access to reproductive technologies for all who would benefit justifies denying access to those who have the means to pay. Such a principle has not been followed with other medical procedures, even life-saving procedures such as heart transplants. As troubled as we might be by differential access, the demands of equality should not bar access for those fortunate enough to have the means.").

23. Id. at 227 ("It is another example of the disparities that differential distribution of wealth in a liberal society inevitably bring.").

24. See Maxwell J. Mehlman \& Jeffrey R. Botkin, Access to the Genome: The Challenge to EQUALITY (1998); Rao, supra note 13; Roberts I, supra note 1, at 939. 
have moved for an emphasis on equality in place of liberty, ${ }^{25}$ while others have asserted that these constitutional rights are not binary and instead liberty requires equal access to ARTs. ${ }^{26}$ In this Section, I argue that procreative liberty requires equal access and, therefore, a positive right to funding for therapeutic PGD where children will otherwise have a reduced life expectancy or significantly impaired quality of life as a result of genetic illness or chromosome abnormality. ${ }^{27}$ I discuss the implications of this argument on the liberty and equality rights of the disabled. It is the addition of the child's liberty to be free of preventable illness to the mother's reproductive liberty to procreate in the manner she chooses that results in a positive right to funding for therapeutic PGD, despite a worrisome impact on the lives of the disabled.

\section{A. The Tension Between Liberty and Equality}

The introduction of PGD in the 1980s was a dramatic advance in reproductive medicine and the study of genetics, since physicians could analyze the genetic makeup of embryos and make decisions about which embryos to implant into a woman seeking to become pregnant. ${ }^{28}$ One main benefit is that, in many cases, a woman no longer needs to conduct tests to determine the embryo's health after implantation and possibly abort that fetus. ${ }^{29}$

The PGD procedure begins with the couple undergoing IVF. The IVF process requires multiple steps: (1) medical suppression of the woman's menstrual cycle, (2) medical stimulation of the woman's ovaries to produce multiple eggs, (3) retrieval of the eggs, (4) collection of sperm from the man, and (5) combination of the sperm and eggs in the laboratory. ${ }^{30}$ After these

25. See, e.g., Roberts I, supra note 1, at 939; Roberts II, supra note 9.

26. See, e.g., Jessica Knouse, Reconciling Liberty and Equality in the Debate over Preimplantation Genetic Diagnosis, 2013 UTAH L. REV. 107; Rao, supra note 13.

27. Beyond questions of liberty and equality, scholars express concerns that nontherapeutic PGD gives parents too much control over their children and may harm them through expectations. Selecting embryos is a "highly instrumental approach to reproduction [that] ... could lead to viewing children as commodities, and undermine their inherent worth and dignity." John A. Robertson, Genetic Selection of Offspring Characteristics, 76 B.U. L. REV. 421, 423 (1996) [hereinafter Robertson III].

28. Daar I, supra note 8, at 247-48 ("Perhaps the most important development in reproductive medicine since the introduction of IVF is a technique known as preimplantation genetic diagnosis (PGD).").

29. Id. at 248 ("The ability to select genetically healthy embryos for transfer into a woman's uterus may reduce the number of elective abortions performed, but the use of PGD has not reduced the controversy that swirls around the medicalization of early life." (footnotes omitted)).

30. Embryo Screening Procedures, Penn Med., https://www.pennmedicine.org/forpatients-and-visitors/find-a-program-or-service/penn-fertility-care/embryoscreening/treatments-and-procedures (last visited Apr. 1, 2017). 
steps are completed and the eggs and sperm have combined to produce embryos, the PGD process begins.

Once the embryo has been cultivated in the laboratory for three days, an embryo biopsy is performed. ${ }^{31}$ At this stage, "[t]he embryos are typically eight-cell embryos ... . and the process involves the removal of one to two cells." ${ }^{32}$ The biopsied cells are then analyzed using one of two techniques, depending on what the couple is interested in testing for-heritable genetic disorders or chromosomal abnormalities. ${ }^{33}$ Once the results are received, the "embryo(s) of the best quality that are not affected by the genetic disorder or chromosomal abnormality) [sic] are selected for transfer to the uterus ... following two additional days of culture in the laboratory." ${ }^{34}$

Alternatively, the biopsy of the embryo can be completed after either five or six days of cultivation, at which point "the embryo consists of many cells and... [c]ells are removed from the outer layer of cells." ${ }^{35}$ After biopsy, all of the embryos with no chromosome abnormalities that are still viable for implantation are frozen. ${ }^{36}$ The same tests are performed on the biopsied cells. Once the results come in, "non-affected or chromosomally normal [embryos] are thawed and transferred" to the uterus. ${ }^{37}$

For both biopsy techniques, if, after the transfer of certain embryos to the uterus, "additional unaffected and good-quality embryos are available, they may be cryopreserved for future embryo transfer." ${ }^{38}$ Those embryos that are affected or that present chromosomal abnormalities are either discarded or donated for use in scientific research. ${ }^{39}$ As of 2014, PGD was

31. Id.

32. Id.

33. Id. (explaining that during these tests the biopsied cells are destroyed "and can't be used for another purpose or returned to the embryo.").

34. Id.

35. Id.

36. Id.

37. Id.

38. Id.

39. See Kathryn Ehrich et al., The Embryo as Moral Work Object: PGD/IVF Staff Views and Experiences, 30 SOc. HEALTH \& ILLNESS 772 (2008). 
utilized in approximately 19,000 IVF cycles. ${ }^{40}$ Of those, PGD for nontherapeutic purposes was used in approximately 1700 cycles. ${ }^{41}$

Currently, PGD can be used for medical selection (to discard embryos with chromosomal abnormalities or genetic mutations that increase the likelihood of a disease in favor of healthy embryos) and sex selection (sometimes used to discard embryos with a sex-linked genetic disease but more often to select sex based on parental preference). While trait selection (selection based on the embryo's physical traits, such as height, eye color, or intelligence) is not yet possible, it dominates the academic debates over the wisdom and ethics of using PGD to select embryos. ${ }^{42}$

In addition to helping parents create healthier babies without genes for inherited diseases, PGD may soon allow parents to choose which embryos to implant based on the embryo's "eye color, hair color, skin color, sex, and even 'disabilities.'" 43 In the United States, there is little regulation of such nontherapeutic applications of PGD. ${ }^{44}$ There are few measures of the demand for nontherapeutic use of PGD (which likely exceeds current technology), although historical demand for favored traits can be shown through favoritism for male children and a preference for children with certain physical traits. ${ }^{45}$

40. National Summary Report, SOC'Y ASSISTED REPROD. TECH., https://www.sartcorsonline.com/rptCSR_PublicMultYear.aspx?ClinicPKID=0 (follow "FILTER" in upper-right-hand corner, select "INCLUDE ONLY" for "PGD/PGS") (last visited Apr. 1, 2017). What Is SART?, SOc'y Assisted ReProd. TECH., http://www.sart.org/patients/what-is-sart/ (last visited Apr. 1, 2017) (noting that in recent years the Society for Assisted Reproductive Technology ("SART") has collected information from its members regarding IVF cycles and the outcomes of those cycles; SART consists of $90 \%$ of ART clinics in the United States).

41. See Harvey J. Stern, Preimplantation Genetic Diagnosis: Prenatal Testing for Embryos Finally Achieving Its Potential, 3 J. CuINICAL MED. 280, 284 (2014) ("Of all PGD cycles reported in 2005, non-medical sex selection was performed in $9 \%$ of cases." (footnote omitted)). This number was reached by utilizing the $9 \%$ figure posited by Harvey Stern, and multiplying that number by the SART number of IVF procedures that utilized PGD.

42. Daar I, supra note 8 , at 250-51.

43. See Knouse, supra note 26 , at 109 (citation omitted).

44. Id. at 109, 121 ("Although it is difficult, if not impossible, to accurately categorize the various tests, some are considered therapeutic while others are considered nontherapeutic. Therapeutic tests are commonly used to detect single gene disorders such as cystic fibrosis, Tay-Sachs, and sickle cell anemia, as well as chromosomal abnormalities such as Down syndrome and Turner syndrome." (footnotes omitted)).

45. Id. at 118-20 ("Throughout history, at least some prospective parents have wanted to select the attributes of their prospective children--sometimes out of a desire to maximize their social status and opportunity and sometimes out of a desire to reproduce themselves. Some prospective parents in patriarchal societies have wanted male children; some in racially stratified societies have wanted blond-haired, blue-eyed, light-skinned children.... While prospective parents have always been able to make general choices about their children's attributes through 'eugenic dating' (and, since the 1960s, through the use of donor 
It is easy to imagine what complications could arise if parents begin to implant only male embryos in large numbers, for example. ${ }^{46}$ Not only would a stigma eventually develop against female children, but there could be long-term consequences for marriage and birth rates reminiscent of problems resulting from China's one-child policy and the use of lessadvanced methods to select male children. ${ }^{47}$ Similarly, selecting embryos based on hair color and eye color would inevitably stigmatize the lessfavored characteristics, particularly as their incidence in the population declined.

The literature debating the wisdom of regulating nontherapeutic uses of PGD-and ARTs more generally-addresses the supposed conflict between the liberty right of parents to be free from government intrusion into procreation and childbearing and the issue of equality, since not everyone has access to this procedure, but focuses largely on the importance of valuing liberty over equality. ${ }^{48}$

material), they could not, until the 1970s, make specific choices about their children's attributes." (footnotes omitted)).

46. I note here, however, that selecting embryos for sex can be therapeutic because some genetic diseases are either only present in one sex or are more prevalent among people of that sex. See id. at 121 ("Testing for sex has therapeutic relevance in that it can prevent $X$-linked diseases such as hemophilia, as well as nontherapeutic (social) relevance for prospective parents who want a child of a given sex." (footnotes omitted)).

47. But see Daar I, supra note 8 , at $265-71$ (arguing against banning PGD to select sex of embryos because it restricts reproductive freedom "in the name of preventing an uncertain harm to others").

48. See Knouse, supra note 26, at 109-10. Some professors argue that the Due Process Clauses of the Fifth and Fourteenth Amendments protect the use of PGD for nontherapeutic reasons. The theory underlying all of the reproductive rights cases, see supra note 16 , is that an individual has a right to decide whether to bear or beget a child. Based on this theory, PGD would seem to be protected as an integral part of that right. This is true whether an individual is using PGD to decide whether to have a child with a disability or not or whether to have a child with a certain eye color or not. Additionally, given how early PGD occurs in the pregnancy, the government's compelling interest in the potentiality of human life would seem to be very low (failing the undue burden standard utilized in abortion cases such as Casey). The difference between non-therapeutic and therapeutic seems more relevant when looking at the undue burden standard, however. Forcing an individual to decide between having a child with a disability or not having a biological child would likely be considered an undue burden on a person's right to bear or beget a child. It would also be hard to argue that therapeutic PGD is not protected because the procedure is focused on the health of the potential human life. The reason the government has any power to restrict the right to abortion is that it has a compelling interest in the health of the mother or the potentiality of human life. On the other hand, forcing an individual to decide between having a child with a certain eye color or not having a biological child likely would not be viewed as an undue burden. Finally, the Court has held in Gonzales v. Carhart, 550 U.S. 124 (2007), that completely restricting access to a certain type of abortion is not unconstitutional as long as there is another 
Robertson defines procreative liberty as "the freedom to decide whether or not to have offspring." 49 According to Robertson, this "deeply held moral and legal value" mandates that the government will almost never have sufficient reason for limiting use of reproductive technology. ${ }^{50}$ This "negative right" is "first and foremost an individual interest," and does not imply a duty to fund those who cannot afford to exercise this liberty. ${ }^{51}$

Robertson believes that procreative liberty should prevent government regulation of nontherapeutic PGD, although he terms the use of embryo selection "quality control." $52 \mathrm{He}$ asserts that the tie between offspring's traits and the decision to reproduce, which is protected by the courts, argues in favor of a procreative liberty that encompasses genetic selection and even genetic alteration of embryos where the ability to determine the offspring's traits affects the decision to reproduce or not to reproduce. ${ }^{53}$

Although Robertson concedes that wealth disparities that prevent uniform access to technologies such as PGD are troubling, his focus is on the importance of parents' liberty to decide when and how to procreate. ${ }^{54}$ As he says, this healthcare problem applies more broadly than in reproduction-"the rich get the benefits, the poor get a few crumbs or

procedure that can be used. It would seem then that the Court might allow nontherapeutic PGD to be banned without banning therapeutic PGD.

49. Robertson II, supra note 20, at 3-4.

50. Id. at 4, 16 ("I propose that procreative liberty be given presumptive priority in all conflicts, with the burden on opponents of any particular technique to show that harmful effects from its use justify limiting procreative choice.").

51. Id. at 22-23 ("The exercise of procreative liberty may be severely constrained by social and economic circumstances. Access to medical care, child care, employment, housing, and other services may significantly affect whether one is able to exercise procreative liberty. However, the state presently has no constitutional obligation to provide those services. Whether the state should alleviate those conditions is a separate issue of social justice."). But see Cass R. Sunstein, Lochner's Legacy, 87 CoLuM. L. ReV. 873, 889 (1987) ("Viewed through the lens of the Lochner period, claims for 'positive rights' cannot be dismissed by reference to the 'negative' character of constitutional guarantees or the word 'deprive' in the in the fourteenth amendment. Whether there is a deprivation depends on antecedent conceptions of entitlement; if there were a pre-existing right to welfare, the failure to provide it would in fact be a deprivation.").

52. Robertson II, supra note 20, at 150-51 ("The term 'quality control' sounds perjorative [sic], but it is the parents' interest in healthy offspring that has spurred these developments.").

53. Robertson III, supra note 27, at 425-27 ("Because reproductive events have such personal significance and impact, the decision whether or not to reproduce should clearly be within an individual's personal discretion." (footnote omitted)). Unsurprisingly based on his argument, Robertson includes within this category of procreative liberty, the use of ART to prevent passing on late-onset genetic diseases such as Huntington's disease, polycystic kidney disease, and Alzheimer's disease, as well as genes that make offspring more likely to inherit diseases such as cancer, heart disease, and even bipolar disorder. Id. at 433.

54. Robertson II, supra note 20 , at 14 . 
nothing"55_but he does not believe that issues of wealth inequality should interfere with access to ARTs for those who can afford them. ${ }^{56}$ While many scholars have critiqued his theory of procreative liberty in the decades since he developed it, ${ }^{57}$ fewer scholars have focused on addressing his admission that "[a]llocating reproductive technologies and other essential goods and services according to ability to pay raises profound questions of social justice." 58

For an individual to access the technologies, (1) there must be a sufficient supply to meet the demand, (2) that individual must have the funds to pay for the services, and (3) the person must know about the technologies and "know to ask for them." 59 While many fear that this country's history of eugenics will result in the use of ARTs to "fix" the gene pool by pushing for their use on the poor, ${ }^{60}$ equally troubling is the predominant use of the technologies by the wealthy to increase their already-existing social advantages by selecting offspring with desirable traits. ${ }^{61}$ Disability rights advocates and other scholars emphasize that the inability of many to afford technologies such as PGD could result in a genetic

55. Id.

56. Id. at 15 ("Discrimination by wealth, however, seems inevitable if reproductive technologies are to be available at all. While some persons would argue that access to reproductive technology should be a mandated benefit in any health insurance program, the high cost of universal health care for the uninsured makes it unlikely that most reproductive technologies will be covered. Other than contraception, abortion, and some prenatal screening, it is likely that access to most reproductive technologies will remain dependent on wealth.").

57. See, e.g., Gilbert Meilaender, Products of the Will: Robertson's Children of Choice, 52 WASH. \& LeE L. Rev. 173 (1995); Laura M. Purdy, Children of Choice: Whose Children? At What Cost?, 52 WASH. \& LeE L. Rev. 197, 198 (1995) (asserting that most feminists "will also be critical of the individualistic stream that runs through his work, as it favors those with more power and disadvantages those who, like white women and people of color, tend to have less").

58. Robertson II, supra note 20, at 225-26 ("A major problem with a rights-based approach is that it ignores the social and economic context in which exercise of rights is embedded.").

59. MeHLMAN \& BotKIN, supra note 24 , at 55 .

60. Id. at 61 ("Eugenics advocates who see genetic technologies as a way to 'perfect' the human gene pool might push for allocation policies that favor persons with relatively poor genetic endowments. These policies also might appeal to liberals as a means of rectifying gross disparities of social status by giving persons of low status access to genetic enhancements that promote upward social mobility.").

61. Id. ("[S]ome people may prefer to reserve scarce genetic resources for those who are gifted with superior genes, on the theory that they would make the best use of them, thereby yielding the greatest amount of social good."). 
arms race that will leave the poor and disabled farther behind. ${ }^{62}$ These fears lead to calls for regulation of ARTs. ${ }^{63}$

The problem with relying on the public's willingness to pay to allocate access to ARTs is that it assumes that individuals have roughly similar wealth and that goods should then be divided based on how strong consumer demand for a particular good is. But wealth disparities undermine this analysis. ${ }^{64}$ It looks like an even worse way to allocate access to genetic selection technologies when one factors in that some have a greater need for access to those services, such as a family history of a grave, genetic illness. ${ }^{65}$

Scholars who have focused on equality in reproductive rights fear that creating a positive right to ARTs will result in government coercion and a lack of meaningful choice due to pressure to use the technology. ${ }^{66}$ Several scholars have therefore proposed limiting the use of ARTs to ensure equality, instead of expanding access. Radhika Rao discusses the "intimate relationship between liberty and equality [that] suggests that courts should strive to ensure equal liberty: limits upon individual liberty and autonomy should be meted out with a measure of equality." ${ }^{67}$ She puts forth a theory

62. Rao, supra note 13 , at 1467-68.

63. Id. at 1474 ("Hence, all persons must possess an equal right, even if no one retains an absolute right, to use ARTs."). Many argue that ARTs aggravate inequality by focusing on the female role to reproduce and by emphasizing genetics to advance racist, sexist, and classist prejudices.

64. MehLMAN \& BotKIN, supra note 24, at 89 ("But willingness to pay runs into a fundamental problem. It might be a satisfactory and perhaps even superior way of allocating access to genetic technologies so long as individuals are able to afford the technologies they desire. Part of what economists who advocate willingnessto-pay approaches mean when they assume that 'all other things are equal' is that everyone has roughly the same amount of wealth. But... as we know from personal experience, this clearly is not the case.").

65. Id. ("Another assumption that economists make is that everyone has the same basic needs for the desired goods, for example, the same risk factors that cause them to need genetic technologies. But this assumption is false . . . As Richard Epstein ... points out, ability to pay does not correlate well with medical need.").

66. See, e.g., Roberts I, supra note 1, at 947-49 (discussing the impact that law and social structures have had on black reproduction and stating that social justice may require that government "reallocate resources away from expensive reproductive technologies").

67. Rao, supra note 13 , at 1488 . The same privacy cases that those favoring reproductive liberty cite to prevent government interference with the right to procreate or not to procreate can be viewed as advocating for equality since they helped women control their reproductive years, their ability to work, and their bodies. Indeed, the cases that are the foundation of a constitutional right to privacy overturn laws that distinguish between different races and classes. $I d$. at 1466-67 (citing Skinner v. Oklahoma - striking down law permitting sterilization of chicken thieves but not embezzlers, Meyer v. Nebraska - striking down law prohibiting foreign language instruction in schools, Pierce v. Society of Sisters striking down law requiring public school attendance, Loving v. Virginia - striking down law banning interracial marriage, Zablocki v. Redhail - striking down law 
of equal liberty, or reproductive liberty, that permits the government to prohibit or limit different ARTs but does not allow distinctions "based upon the status of the persons involved." 68 Only laws that allow all to use ARTs, including sexual minorities and the unmarried for example, would be constitutional. ${ }^{69}$ Banning therapeutic or nontherapeutic PGD is constitutional under Rao's framework. ${ }^{70}$

Dorothy Roberts more strongly advocates limiting the use of ARTs. The correlation between race and socioeconomic status means that race plays a large role in any discussion of equality in the use of ARTs. Even the supposedly noble goal of therapeutic PGD must still contend with the notion that many of the poor (more likely to be minorities) do not place the same value on genetic ties and should not be coerced into using ARTs when other options, such as not having children, using sperm donors, or adopting children, are available. As Roberts writes, "I have also noticed that America is obsessed with creating and preserving white genetic ties. Trading the genetic tie on the market lays bare the high value placed on whiteness and the worthlessness accorded blackness." ${ }^{71}$ Given the high price of racial discrimination in the United States, the potential for parents to manipulate genes to alter the race of embryos is not speculative. Roberts questions whether limiting the use of ARTs sacrifices too much liberty on the altar of equality, but in the end, believes that imposing such limits is the best solution to issues of modern reproduction and inequality. ${ }^{72}$

Other solutions scholars propose focus on equality, including using the money that is saved by avoiding genetic diseases to fund increased ART

requiring court approval prior to marriage for any individual with an outstanding child support obligation, and Lawrence $v$. Texas - striking down law prohibiting same-sex sodomy).

68. Id. at 1460 ("Why provide equal but not absolute rights in the realm of assisted reproduction? The principle of reproductive liberty has no logical stopping point; it confers constitutional protection upon almost every technology that is necessary to procreation.... It subjects all laws that restrict reproductive autonomy to strict judicial scrutiny and requires them to be struck down unless necessary to advance compelling governmental objectives." (footnotes omitted)); cf. Andrew B. Coan, Assisted Reproductive Equality: An Institutional Analysis, 60 CASE W. RES. L. REV. 1143 (2010) (calling for additional comparative institutional analysis of Rao's proposal).

69. Rao, supra note 13 , at 1460 .

70. Id. at 1482.

71. Roberts II, supra note 9, at 210-11 (arguing that the genetic tie is not based on biology but instead a method "that promotes racist and patriarchal norms"). Roberts finds that the most socially significant genetic link between parents and child is race. $l d$. at 223.

72. Roberts I, supra note 1 , at 948-49. Roberts supports equal access to ARTs through government subsidies and legislation requiring their inclusion in private insurance coverage, although she believes the use of ARTs ultimately should be restricted. Id. at 946-47. 
use, ${ }^{73}$ mandating insurance coverage for technology use, ${ }^{74}$ providing assistance to those with greater needs for the technology through charity, ${ }^{75}$ and even using genetic lotteries. ${ }^{76}$ Most proposed solutions focus on therapeutic PGD and not nontherapeutic PGD. ${ }^{77}$ Jessica Knouse, however, proposes subsidizing nontherapeutic PGD as one solution that promotes both liberty and equality. ${ }^{78}$ Given the demand for services that would likely result if subsidies for nontherapeutic PGD were large enough to rectify equality concerns, however, this proposal would be a very costly one.

\section{B. Liberty for the Disabled}

Any proposal to fund PGD use to screen out genetic illness or chromosomal abnormalities impacts the disabled. Many of those with disabilities view themselves as subject to an unfair social stigma rather than burdened by their disabilities. ${ }^{79}$ Efforts to deselect embryos for disabilities can be seen as a failure to understand the value of the lives of the disabled.

73. MehLMAN \& BotKIN, supra note 24, at 105-06 ("The problem is that, surprising as it may sound, it simply is not clear that preventing illness saves money. No doubt it may reduce the costs of acute care in the short run, but in the long run, the people who would have died from acute ailments would go on to live longer and to contract the expensive, chronic illnesses of old age."). This point, however, excludes the many additional years of insurance premium payments that companies would collect along the way.

74. Id. at 107 ("The only technologies that might be excluded from coverage due to cost would be those that were expected to yield only trivial benefits.... However, this assumes that we could define which benefits were trivial.").

75. Id. at 111 ("If organized charities stepped in to finance access to genetic technologies, they might well allocate their funds on the basis of judgments about the recipients' character, or their social worth, or on the basis of their religion or ethnicity, all of which might raise complaints of favoritism and unfairness that could lead to government intervention.").

76. See id. at ch. 7.

77. But see Judith DaAr, The New Eugenics: Selective Breeding in an Era of Reproductive TECHNOLOGIES 193-95 (2017) [hereinafter Daar II] (calling for broad increases in insurance coverage, "reduced-cost treatment strategies", and additional charitable provision for ART to make it more accessible to those who cannot afford it).

78. Knouse, supra note 26 , at 152 ("This is not to say that subsidies are unequivocally the best policy, simply that they appear most likely to enable the expression of genetic and ideological diversity. If future studies revealed that this was not accurate--because prospective parents were, for example, consistently selecting against given eye, hair, and skin colors, or against a given sex--reassessment would of course be required.").

79. See Samuel R. Bagenstos, Disability, Life, Death, and Choice, 29 HARV. J. L. \& GENDER 425, 435-36 (2006) [hereinafter Bagenstos I] (noting that many disability rights advocates view the "greatest suffering of people with disabilities [as] the socially stigmatized identity inflicted upon them" and argue that the solution is not to treat or eliminate disabilities but instead to eliminate the stigma and stop devaluing disabled lives (internal footnotes omitted)). 
In addition, funding for therapeutic PGD may create pressure to deselect embryos because doing so is what the government and society believe is right. As the number of disabled people decreases, the social stigma of being different is likely to increase. While the amount of resources spent to aid the disabled may not necessarily decrease, the community will be smaller, and views of the disabled will be different, because of efforts to screen out genetic illness and resulting disabilities.

Although I discuss these implications of my argument below in Section III, here I address the main focus of the health law literature in addressing liberty for the disabled-the small percentage of parents who seek to use PGD to produce children with traits that many consider to be disabilities, such as deafness or dwarfism. The fact that this is the topic that dominates discussions of reproductive rights with ARTs and the disabled shows the extent to which liberty still dominates equality in the literature on ARTs and also the implications for the disabled of any positive right to PGD. Some disabled parents want to bring children into a culture that is an integral part of their lives, ${ }^{80}$ but health law scholars have been largely critical and coined the phrase "intentional diminishment." 81

My focus here is on how the ability to eliminate disabilities through methods such as therapeutic PGD creates an "in" group and "out" group. Given that the "out" group already struggles with feeling different and isolated, further use of ARTs by wealthy whites will only enhance the idea of two genetic classes: those with healthy or better genes and those without, the healthy babies and the sick babies.

Under Robertson's procreative liberty framework, the decision to reproduce could be fundamentally affected by whether a couple can have a child who is deaf or has a form of dwarfism, leading to the conclusion that PGD to intentionally produce a child with a disability should be permitted under the law. Here, however, the liberty runs up against a demonstration of "tangible harm to others [that] would justify restriction." 82 Families who

80. See Darshak M. Sanghavi, Wanting Babies Like Themselves, Some Parents Choose Genetic Defects, N.Y. TIMES (Dec. 5, 2006), http://www.nytimes.com/2006/12/05/health/05essa.html?_r=0 (“Traditionally, cultures were perpetuated through assortative mating, with intermarriage among the like-minded and the like-appearing. Modern technology has been adopted for this purpose....").

81. See I. Glenn Cohen, Intentional Diminishment, the Non-Identity Problem, and Legal Liability, 60 Hastings L.J. 347, 349 (2008) [hereinafter Cohen I] (“While Smolensky discusses creating 'children with disabilities,' I will from here on out use the phrase 'intentional diminishment,' which I will define as intentionally using reproductive technology to produce a child who is on balance significantly harmed as compared to the 'normal' child (think of 'diminishment' as the antonymic concept to 'enhancement,' which is often discussed in the bioethics literature).").

82. Robertson III, supra note 28 , at 439. Robertson believes that ignoring genetic test results (whether the testing is mandatory or voluntary) and producing "unavoidably handicapped offspring" does not harm the children because there is no other outcome possible. Robertson says there is "in most cases no wrongful life." He continues, "As long as persons who choose to ignore genetic information 
believe that being a member of the deaf community, for example, is beneficial to a child would dispute the notion that being deaf is harmful to a child or argue that this harm is balanced by the benefits of participation in a vibrant and cohesive community. Scholars have largely opposed the use of PGD and other ARTs to produce disabled children, however. ${ }^{83}$

The health law literature's focus on the use of ARTs to affirmatively produce children with disabilities is a response to claims that reproductive technology will result in a modern form of eugenics and a desire by some to prevent forced genetic selection. From the late 1880s to the early twentieth century, the eugenics movement in the United States asserted that selective breeding could improve society by eliminating bad genes. One result was that over 60,000 supposed undesirables, including the mentally ill, criminals, drug addicts, the blind, orphans, and the homeless were involuntarily sterilized..$^{84}$ PGD raises concerns that it would either: 1 ) result in an "in" group of wealthy whites who deselect embryos with disabilities or select embryos with favored characteristics, stigmatizing those who cannot afford the technology or do not want to use it for other reasons or 2) force or coerce those with a gene that results in disabled offspring to deselect embryos with the gene, regardless of their preference, if the law mandates such a policy. ${ }^{85}$ Because the second possibility is most

in reproducing are able and willing to rear affected offspring, the costs of their reproduction are unlikely to be sufficient to support a charge of reproductive irresponsibility. Public action to prevent the birth of genetically handicapped offspring by mandatory means is thus not justified." Robertson II, supra note 20, at 152.

83. Scholars have even speculated whether children born with a disability that was intentionally selected by the parents using PGD could sue their parents under tort law. See Kirsten Rabe Smolensky, Creating Children with Disabilities: Parental Tort Liability for Preimplantation Genetic Interventions, 60 HASTINGS L.J. 299, 344 (2008) (arguing that parents who use PGD to select embryos with disabilities - as opposed to parents who may in the future be able to edit the DNA of embryos to intentionally diminish children - cannot be sued because they "do not create a legally cognizable injury to the born-alive child because of the Non-Identity Problem" which dictates that there is no harm because the child would not otherwise exist). But see Cohen I, supra note 81 (evaluating Smolensky's arguments and taking issue with her attempt to distinguish manipulation from selection and to argue that the Non-Identity Problem prevents liability in the case of PGD).

84. Daar I, supra note 8, at 260-61.

85. "As genetic screening increasingly enables individuals to manage their own health by reducing genetic risk, we may see its wider incorporation into the health care system. Using reprogenetics to select the traits of children may become more of a general duty than a privileged choice. Widespread prenatal testing has already assigned pregnant women primary responsibility for making the 'right' genetic decisions." Dorothy Roberts, Fatal Invention: How SCIence, Politics, and Big Business Re-Create Race in the TWenty-First Century 217 (2011) [hereinafter Roberts III]. "[I]n her book exploring the public consequences of private decisions about reproductive technologies, Lynda Beck Fenwick suggests readers ask themselves, 'Are you willing to pay higher taxes to cover costs of government benefits for 
similar to the American history of eugenics-and thus more likely to provoke great backlash and protest-scholars have focused on the first, more invidious possibility.

Robertson argues that choosing not to have disabled children does not inherently harm those who are currently disabled. As he states, "A policy to prevent accidents that cause paraplegia does not harm existing paraplegics, nor prevent us from supporting programs that make their lives easier." ${ }^{86}$ Robertson misses the point, however, that as the number of people who are disabled declines, it is likely that supportive policies will decline, particularly as the wealthy opt out of disabilities. If the wealthy can avoid having disabilities, they are less likely to lobby for government funding for the disabled or to contribute to charities that support the disabled.

If PGD can be used to screen out disabilities, it will inevitably stigmatize individuals living with disabilities. As Robertson states:

Persons or families with disabled children have claimed that a policy that encourages prebirth genetic deselection of persons with disabilities is a public statement that the lives of the disabled are worth less than those of the able-bodied. In addition, such a policy reduces the number of persons with those disabilities, thus reducing their political effectiveness.... In short, it engenders or reinforces public perceptions that the disabled should not exist, making intolerance and discrimination toward them more likely. ${ }^{87}$

This is one plausible argument for either rejecting any expansion of the use of PGD or allowing those who have genetic disabilities to perpetuate their community through procreation, particularly given the United States' murky past.

babies born with genetic defects, even when the parents knew of the high likelihood or certainty such defects would occur.' This question suggests that the main objective of a state-supported reprogenetics program would not be to give individuals more reproductive choices but to escape public responsibility for disability-related needs.... In the future, the government may rely on the expectation that all pregnant women will undergo genetic testing to justify not only its refusal to support the care of disabled children, but also its denial of broader claims for the public provision of health care. Without a right to basic health care, more widespread use of genetic technologies could come at the expense of public health." Id. at 221.

86. Robertson III, supra note 27, at 453.

87. Id. at 453 (footnote omitted). Rao says "it should be (a) relatively easy for the state to make the case for allowing PGD to select against a serious disease that would cause death, (b) more difficult but still possible to justify PGD to select against a 'disability' that arguably decreases quality of life, such as deafness, but (c) much more difficult, and perhaps impossible, to defend PGD to select for traits such as sex, skin color, and sexual orientation that are disfavored solely because of negative societal attitudes and prejudice." Rao, supra note 13, at 1484 (footnotes omitted). 
Judith Daar, however, argues against the idea that therapeutic PGD will lead to a slippery slope back to eugenics. First, selective abortions serving the same purpose have been and are available, but do not produce the same fears. Second, although there are fears that parents will look to produce the perfect child, everyone's definition of perfect is different, as shown by the parents who are willing to go to great lengths to have a child who is deaf or has dwarfism. ${ }^{88}$ I would add, though, that the parents who seek to produce children with disabilities are, in part, reacting to a culture of inequality; rather than defining their perfect child, they seek to defend those considered diminished by growing their numbers.

Who defines what genes are good and bad? The answer is less obvious outside of the example of genetic illness. Ensuring greater access to ARTs results in a larger, more diverse population deciding which genes are desirable and defending their communities. ${ }^{89}$ In Section II, I look at how recent disputes relating to PGD already have a negative impact on the disabled and show that not enough attention has been paid to the creation of a bifurcated system of procreation.

\section{PGD and the Courts}

The most pressing questions before courts related to PGD are who determines when and whether the embryos are implanted and what happens when the wrong embryo is implanted (and, of course, what constitutes the wrong embryo). Where courts once hesitated to consider death an injury that resulted in a valid legal claim, the now-accepted wrongful death claim has given way to attempts to gain recognition for a wrongful life tort. ${ }^{90}$

A significant amount of scholarship has addressed the growing demand for recognition of wrongful life as a tort. ${ }^{91}$ Much has been made about the

88. Daar I, supra note 8, at 262-64 ("If our society is interested in preventing intentional diminishment by birth parents, any regulatory scheme must be directed at all prospective violators, not just those who require assistance to procreate.").

89. See Roberts III, supra note 85 , at 220 ("Although government welfare systems have disdained facilitating childbearing by poor women of color by declining to fund fertility treatments, they may treat prenatal genetic testing quite differently. The very same thinking that promotes laws and policies that pressure these women to have fewer children could promote laws and policies that pressure them to have genetically screened children.").

90. Becker v. Schwartz, 386 N.E.2d 807, 808 (1978) (“Although no longer shackled by the conceptual difficulties formerly posed by a 'wrongful death' action, courts have again been drawn toward the murky waters at the periphery of existing legal theory to test the validity of a cause of action for what has been generically termed 'wrongful life.'").

91. See, e.g., Dov Fox, Reproductive Negligence, 117 Colum. L. REv. 149, 241 (2017) (advocating for a new cause of action to address "reproductive injuries"); Wendy F. Hensel, The Disabling Impact of Wrongful Birth and Wrongful Life Actions, 40 HARV. C.R.-C.L. L. REV. 141, 143-45 (2005) (acknowledging the existence of scholarly 
comparison between living a life with a disease or other genetic abnormality and living a healthy life (or living no life at all if the comparator is never having been born). ${ }^{92}$ What scholars have not addressed is how disputes over implanting the wrong embryos and increasing this tort's recognition would affect children born with the same genetic abnormalities who were not conceived through ARTs. If something goes awry in the PGD process and a child can recover because the wrong embryo was implanted, this creates a stigma for those born with preventable diseases or conditions whose parents either did not know about PGD or could not afford to utilize it. ${ }^{93}$ The children conceived through PGD could also recover the medical and long-term care costs associated with the condition, even though they are more likely to be the children of those who can afford to bear such costs.

The resolution of custody disputes relating to frozen embryos further serves to stigmatize those without access to therapeutic PGD by emphasizing the exceptional importance of having a genetic child and creating the inference that the chance to have a healthy genetic child would merit even greater legal protection. When the last chance to have a genetic child can outweigh another person's right not to be a parent, then the last chance to have a healthy genetic child is likely to trump that right as well. ${ }^{94}$

Dov Fox recently proposed a framework for addressing "reproductive negligence" that recognizes that "[t]he harm is being robbed of the ability to determine the conditions under which to procreate." 95 Rejecting "a legal system that treats heedlessly switched sperm, lost embryos, and misdiagnosed fetuses not as misconduct that it protects against and compensates victims for, but as misfortune that it tolerates and forces them to abide," ${ }^{96}$ Fox outlines a unified legal claim to address the distinct harms that negligence in assisted reproduction causes. ${ }^{97}$ His article never

research supporting the recognition of the tort of wrongful life); Matthew Reisman, Note, Harm and the Fluid Nature of Identity in Wrongful Life Cases Involving Preimplantation Genetic Diagnosis, 20 CARDOZO J.L. \& GENDER 405, 407-09 (2014) (arguing that the wrongful life tort fits within the existing jurisprudence regarding negligence torts).

92. See, e.g., Hensel, supra note 91, at 161; Reisman, supra note 91, at 422; Alexander D. Wolfe, Wrongful Selection: Assisted Reproductive Technologies, Intentional Diminishment, and the Procreative Right, 25 T.M. COOLEY L. ReV. 475, 489 (2008).

93. See, Hensel, supra note 91; Marley McClean, Note, Children's Anatomy v. Children's Autonomy: A Precarious Balancing Act with Preimplantation Genetic Diagnosis and the Creation of "Savior Siblings", 43 PEPP. L. ReV. 837, 865 (2016).

94. See infra notes $121,124-31,133-41$ and accompanying text.

95. Fox, supra note 91 , at 155.

96. Id.

97. It is worth noting that, as Fox acknowledges, his proposed legal framework will increase the cost of ARTs. He proposes an option such as damage caps "that balances the freedoms that reproductive treatment enables against the injuries that it can inflict." Regardless, the additional liability will further reduce access without additional insurance or government subsidies. See id. at 214. 
mentions the impact of this claim on those without access to the means to effectuate their reproductive rights. Should they have a claim because they have been "robbed of the ability to determine the conditions under which to procreate?" 98 If not, any such legal right places those with access above those without, an exacerbation of the current legal framework that I review below.

The courts have not protected the right of those who cannot afford to undergo therapeutic PGD to have similarly healthy genetic children. As courts increasingly protect the rights of parents and children to deselect embryos with unhealthy genes, access to reproductive rights should be a key component of the jurisprudence.

\section{A. Tort Law}

Approximately one in five IVF clinics "report errors in diagnosing, labeling, and "handling samples or embryos."'99 As more people use therapeutic PGD, lawsuits that argue negligence in cases where children are born with a chromosome abnormality or a gene for a genetic disease in spite of efforts to only implant healthy embryos will increase. Prior to the development of PGD, these lawsuits focused on alleged negligence related to the genetic testing of fetuses. Some lawsuits included claims using a tort of wrongful birth and focused on the parents' injury because they were unable to abort the fetus since the disability or illness was not diagnosed in utero. ${ }^{100}$ Wrongful life actions on the child's behalf allege that the negligence "enabled the child to come into being, the operable injury is the child's life itself, with non-existence identified as the preferred alternative." ${ }^{101}$ Generally, courts have favored wrongful birth claims but not wrongful life claims, while scholars have typically defended both actions. ${ }^{102}$

Courts identified two problems with recognizing a wrongful life cause of action-the lack of a legal injury, and the lack of a proper remedy to put the injured party in the same position he or she would have been in absent

98. See id. at 177 ("[Reproductive decisions] vindicate not just decisional autonomy (how freely she chooses), but also individual well-being (how well such outcomes help her live).").

99. Id. at 152 (citation omitted).

100. See, e.g., Becker v. Schwartz, 386 N.E.2d 807, 809-14 (1978) (rejecting wrongful birth claims in companion cases where plaintiffs, respectively, sued because Becker had a child with Down's Syndrome after she was not advised by her doctor of the increased risk beyond age 35 or of the possibility of having an amniocentesis test and Park had a second child after her doctor incorrectly told her polycystic kidney disease is not hereditary); see also Fox, supra note 91, at 169 ("Wrongfulbirth actions fail to fully consider the separate and serious harm that victims of reproductive negligence suffer. Their complaint is not that the child they received is undesired or undesirable; it is that they have been denied the chance to decide whether to gestate or parent.").

101. Hensel, supra note 91 , at 143.

102. Id. 
the injury. In Becker v. Schwartz, the court argued that it lacked the competence to decide " $[\mathrm{w}]$ hether it is better never to have been born at all than to have been born with even gross deficiencies." ${ }^{103}$ Concerned not only with a lack of precedent but with the implications of its decision, the court continued, "Would claims be honored, assuming the breach of an identifiable duty, for less than a perfect birth? And by what standard or by whom would perfection be defined?" 104 The majority of jurisdictions support wrongful birth claims, while only a few-California, New Jersey, and Washington-allow wrongful life actions. ${ }^{105}$

PGD has not to this point substantially changed the law in this area from that which existed with other forms of prenatal screening. ${ }^{106}$ Yet the counterfactual differs in the case of PGD. In prior cases, the alternative, absent improper genetic counseling and testing during pregnancy, was an abortion. Wrongful life suits were rarely successful because the alternative to the difficult life of the child with the chromosome abnormality or disease that the parents sought to avoid through intervention was non-existence. Now, the comparison can be the harm between implanting a healthy embryo and the unhealthy embryo that was mistakenly implanted. ${ }^{107}$

The transition between technologies can be seen in Paretta v. Medical Offices for Human Reproduction. ${ }^{108}$ In that case, the Parettas conceived by creating an embryo from a carefully selected egg donor and Gerard Paretta's sperm. Although the egg donor was a known carrier of cystic

103. Becker, 386 N.E.2d at 812 ("Simply put, a cause of action brought on behalf of an infant seeking recovery for wrongful life demands a calculation of damages dependent upon a comparison between the Hobson's choice of life in an impaired state and nonexistence.").

104. Id.

105. Hensel, supra note 91, at 161-62; see Procanik v. Cillo, 478 A.2d 755, 762-63 (1984) (rejecting a wrongful life claim for general damages but allowing the recovery of extraordinary medical expenses, stating that the decision "is not premised on the concept that non-life is preferable to an impaired life, but is predicated on the needs of the living"); Turpin v. Sortini, 643 P.2d 954, 957-59 (1982) (finding that "it is hard to see how an award of damages to a severely handicapped or suffering child would 'disavow' the value of life or in any way suggest that the child is not entitled to the full measure of legal and nonlegal rights and privileges accorded to all members of society").

106. See Kate Wevers, Note, Prenatal Torts and Pre-Implantation Genetic Diagnosis, 24 HARV. J.L. \& TECH. 257, 266-67 (2010).

107. Id. at 268 ('From the parents' perspective, the counterfactual in a case of postpregnancy negligence is abortion. The counterfactual in a case of preconception negligence is not conceiving. In a PGD context, however, the most likely counterfactual is that the parents would have given birth at the same time to a different child with the same genetic parents."); Reisman, supra note 91, at 40708 (arguing that if one uses Parfit's work on identity to assume that an embryo lacks an identity, then selecting one embryo or another does not change the identity of the child born but instead only the characteristics of that individual).

108. See Paretta v. Med. Offices for Human Reprod., 195 Misc. 2d 568 (N.Y. Sup. Ct. 2003). 
fibrosis, no one ever told the Parettas or tested Mr. Paretta. The baby was conceived using IVF and born with the disease. Although Becker prevented any recovery on the child's behalf or for the parents' emotional distress, the Paretta court distinguished Becker because there was no claim in Becker that the "physicians' treatment caused the abnormalities in the child." ${ }^{109}$ In Paretta, however, the plaintiffs alleged that the doctors "had a role in [the child's] genetic composition." 110 Ultimately, though, the court refused to take the next step and found that the child, "however, like any other baby, does not have a protected right to be born free of genetic defects." ${ }^{111}$ Any other conclusion would give children conceived with ARTs "more rights and expectations than children conceived without," 112 which is exactly the concern with increasing recognition of a wrongful life tort.

Yet it seems unlikely that tort law will not find a way to compensate couples who expect to produce a child free of genetic defects-because that is what the medical service they are buying purports to provide-and produce an unhealthy child as a result of negligence. The injury is apparent if we assume that parents have a right to select particular offspring or design their families in a way that fertility clinics advertise.

A review of recent cases addressing failures of PGD to produce healthy children shows, however, that most courts are still reluctant to find that an injury exists when parents conceive an unhealthy child. In Doolan v. IVF America (MA), Inc., ${ }^{113}$ the court found that a child conceived with cystic fibrosis in spite of attempts to select a healthy embryo through PGD did not have a negligence claims against the hospital. Rejecting what it viewed as a wrongful life claim, the court stated:

[T] he essence of Thomas Doolan's claim is not that the alleged negligence of the defendants caused him to be born with cystic fibrosis, but rather that the alleged negligence of the defendants denied his parents the opportunity to choose not to conceive and give birth to him. This is precisely the 'fundamental problem of logic' that the [Supreme Judicial Court of Massachusetts] sought to avoid. ${ }^{114}$

109. Id. at 575 .

110. Id.

111. Id. at 576 .

112. Id.

113. See Doolan v. IVF Am., Inc., No. 993476, 2000 WL 33170944 at *5 (Mass. Super. Nov. 20, 2000).

114. Id. at *4; Even in California, which recognizes the tort of wrongful life, some judges have found reasons to reject PGD tort claims. In Bergero v. University of Southern California Keck School of Medicine, No. B200595, 2009 WL 946874 (Cal. Ct. App. Apr. 9, 2009), the parents of Gabriel Rubell Bergero attempted to use PGD through a procedure called polymerase chain reaction (PCR) to deselect embryos with Fabry disease. Although experienced with IVF, the University of Southern California (USC) had only performed IVF for PCR once or twice before Gabriel's 
As the use of PGD increases and its cost declines with increasing efficiency and economies of scale, there will inevitably be more attempts to expand recognition of the tort of wrongful life. The more reliable the technology becomes, the more actionable negligence seems. With recognition that a fertility clinic's negligence resulted in the selection of the wrong embryo and a large emotional and financial burden on the parents and the child, the law will find a way to compensate for this injury.

One concern with the tort law claims is the effect they have on the disabled, who are inevitably stigmatized by the idea that the disability makes life so meaningless that the disabled embryo should never have been selected or the parent should have been given the choice to abort the child. ${ }^{115}$ Although many scholars argue practically that there is a child who needs care and these suits are only a method to obtain money to improve the child's quality of life, others argue that the harm to the disabled as a group presents a larger problem. ${ }^{116}$

case. Id. at *3. After testing, Gabriel's parents agreed to implant two embryos that they thought were female Fabry carriers since none of the embryos were Fabry free and the symptoms are typically much less severe in women. Pregnancy with a male child afflicted with Fabry resulted. Id. at *4.

The IVF specialist at USC, Dr. Richard Paulson, "conceded that Rubell might have wanted to know about USC's limited IVF for PCR experience. He also stated that he understood a patient might want to know that USC's IVF for PCR procedures were performed eight to 10 months apart." Id. at *11. The jury concluded, however, that USC was not negligent, and the appellate court affirmed, because in informed consent cases the physician's failure to inform must cause the injury to the plaintiff. A physician is only liable where a reasonable person would not have gone forward with the treatment had she known the information. See also Doe v. Illinois Masonic Medical Center, 297 III. App. 3d 240 (1998) (denying plaintiffs access to hospital documents where they participated in a hospital program designed to reduce the incidence of cystic fibrosis through PGD and, subsequently, gave birth to a baby girl with cystic fibrosis).

115. See Hensel, supra note 91, at 144 ("Wrongful birth and wrongful life suits may exact a heavy price not only on the psychological well-bring of individuals with disabilities, but also on the public image and acceptance of disability in society. Rather than focusing on a defendant's conduct, as in a traditional tort action, both wrongful birth and wrongful life suits ultimately focus on the plaintiff's disability, a status that is at least partially a societal construction.").

116. See, e.g., id. ("Any benefits secured by individual litigants in court are thus taxed to the community of people with disabilities as a whole, placing at risk, in the drive for individual compensation, the gains secured by collective action and identity."). 


\section{B. Family Law}

As the use of IVF has increased, so have disputes over frozen embryos, ${ }^{117}$ particularly in the event of divorce. ${ }^{118}$ Either couples do not consider before creating embryos what should happen in the event of unforeseen circumstances, or courts refuse to enforce their agreements. ${ }^{119}$ PGD will likely change this body of law because it increases the degree of attachment and, at times, desperation that those fighting for the right to use the embryos will feel. Those utilizing IVF and therapeutic PGD to create embryos have, on average, spent more money trying to conceive than those using IVF alone. Because these prospective parents discard or deselect unhealthy embryos, it frequently takes more IVF attempts to create healthy embryos to implant. This results not only in a more time-consuming process but also in more discomfort for the woman producing the eggs and in anxiety for the couple.

In addition, the question remains whether and how courts will factor into the analysis the possibility that, if the parent seeking to use the embryos is also the one with the genetic condition that caused the couple to use PGD and is not granted the right to implant the embryos, he or she may then be more likely to have a child through natural methods to avoid the additional expense and effort. This could result in sick babies instead of healthy babies. I first review current frameworks for deciding embryo disputes and then argue that an increase in the use of therapeutic PGD will result in greater use of the balancing test and further serve to emphasize the value and importance of babies created using PGD.

Courts have utilized different frameworks for deciding embryo disputes: (1) a contractual framework, (2) a contemporaneous mutual

117. Courts differentiate between the embryo and pre-embryo stages of fertilization. "The pre[-]embryo comes into existence with the first cell division and lasts until the appearance of a single primitive streak, which is the first sign of organ differentiation. This [primitive streak] occurs at about fourteen days of development." See Litowitz v. Litowitz, 48 P.3d 261, 262, amended sub nom. In re of Marriage of Litowitz, 53 P.3d 516 (Wash. 2002) (alteration in original) (internal quotation marks omitted) (citations omitted). This article will use the term embryo to refer to both embryos and pre-embryos.

118. See, e.g., Deborah L. Forman, Embryo Disposition, Divorce \& Family Law Contracting: A Model for Enforceability, 24 COLUM. J. GENDER \& L. 378, 387-81 (2013); Mark P. Strasser, You Take the Embryos But I Get the House (and the Business): Recent Trends in Awards Involving Embryos Upon Divorce, 57 Buff. L. REV. 1159, 1159 (2009); Angela K. Upchurch, The Deep Freeze: A Critical Examination of the Resolution of Frozen Embryo Disputes Through the Adversarial Process, 33 FLA. ST. U. L. REV. 395, 396 (2005).

119. See Michael T. Flannery, "Rethinking" Embryo Disposition Upon Divorce, 29 J. CONTEMP. HeALTH L. \& Pol’y 233, 233 (“This problem arises either because couples fail to expressly state their intent for disposition upon divorce through contract, or public policy renders such contracts unenforceable."). 
consent framework, and (3) a balancing framework. ${ }^{120}$ Because many fertility centers require clients to decide what will be done with the embryos before they are created, particularly in the event of divorce, courts frequently enforce these agreements using a contractual framework, which typically prevents the use of the embryos after a separation. ${ }^{121}$ Even scholars who use contractual principles of interpretation to argue against the use of embryos after divorce where an agreement is made ex ante to allow the use of the embryos after divorce make an exception, however, for a party who has no other chance to conceive. ${ }^{122}$

Under the contemporaneous mutual consent framework, both parents must agree to implant the embryos for one parent to use them, regardless of what any previous written agreements state on the disposition of those embryos. Only lowa endorses this framework. ${ }^{123}$ In re Marriage of Witten ${ }^{124}$ applied the contemporaneous mutual consent framework, refusing to enforce an embryo-storage agreement signed by Tamera and Arthur Witten but also refusing to allow Tamera Witten to use the embryos to conceive a child. Looking not just at precedent but also at legal scholarship, the lowa Supreme Court found that "[t]he contractual approach and the contemporaneous mutual consent model share an underlying premise: 'decisions about the disposition of frozen embryos belong to the couple

120. Id. I take no position on debates over what should happen to the embryos if not implanted. Currently unregulated, that is a subject beyond the scope of this paper.

121. See Litowitz, 48 P. $3 d$ at 268-71 (enforcing agreement with fertility center to thaw and discard embryos five years after cryopreservation unless parties mutually agreed to extend the contract in spite of later changes between the biological father and intended mother of the embryos); Kass v. Kass, 696 N.E.2d 174, 180-82 (N.Y. 1998) (enforcing parties' prior consent form to donate embryos to research in the event of divorce and noting that "[a]dvance agreements as to disposition would have little purpose if they were enforceable only in the event the parties continued to agree"); Davis v. Davis, 842 S.W.2d 588, 597 (Tenn. 1992) (concluding in dicta that ex-ante agreements on disposition of embryos at certain contingencies should be enforced unless superseded by later mutual agreement); cf. A.Z. v. B.Z., 725 N.E.2d 1051, 1057-59 (Mass. 2000) (finding husband's consent to wife's control of embryos after separation on the fertility center's consent form invalid because incomplete but stating that agreement would be enforceable regardless for public policy reasons); Dara E. Purvis, Expectant Fathers, Abortion, and Embryos, 43 J.L. MED. \& Ethics 330, 335 (2015). But see Alex M. Johnson, Jr., The Legality of Contracts Governing the Disposition of Embryos: Unenforceable Intra-Family Agreements, 43 Sw. L. ReV. 191, 193-96 (2013) (arguing that these agreements should be viewed as gratuitous promises based on the marital relationship existing at the time that are unenforceable in the event of divorce).

122. See, e.g., Johnson, Jr., supra note 121, at 203 (finding that reliance may justify enforcing agreements where "the inability of one of the parties to exercise their reproductive ability in the future without the use of the gametic material that is the subject of the disputed agreement, which fact is known to the other contributor of gametic material at the time of contribution" (citation omitted)).

123. Purvis, supra note 121 , at 335.

124. In Re Marriage of Witten, 672 N.W.2d 768 (Iowa 2003). 
that created the embryo, with each partner entitled to an equal say in how the embryos should be disposed.'" 125

The difference between the two frameworks is the question of when the parties must consent. Citing research on frequent changes in decisions about embryo disposition before and after creation, the lowa court chose the contemporaneous mutual consent approach because it requires that neither partner remove the embryos from cryostorage and use them in any way unless the other partner consents at the time of removal. ${ }^{126}$ The lowa court noted that it

think[s], however, that it would be against the public policy of this state to enforce a prior agreement between the parties in this highly personal area of reproductive choice when one of the parties has changed his or her mind concerning the disposition or use of the embryos. ${ }^{127}$

Courts have generally held that one parent's right not to be a parent outweighs the other parent's right to have a baby when using the third framework, a balancing test. ${ }^{128}$ Notably, however, there is "a different balance when the stored pre-embryo may be the mother's last chance to be a genetic mother ... [and] the circumstances overcome the right not to

125. Id. at 777 (quoting Carl H. Coleman, Procreative Liberty and Contemporaneous Choice: An Inalienable Rights Approach to Frozen Embryo Disputes, 84 MINN. L. REV. 55, 81 (1999)).

126. Id. at 778 ("Although this model precludes one party's use of the embryos to have children over the objection of the other party, the outcome under the contractual approach and the balancing test would generally be the same." (citation omitted)).

127. Id. at 780-81; see id. at 783 ("The practical effect will be that the embryos are stored indefinitely unless both parties can agree to destroy the fertilized eggs. Thus, any expense associated with maintaining the status quo should logically be borne by the person opposing destruction." (citation omitted)).

128. See Johnson, Jr., supra note 121, at 222-24 (noting that courts have refused to enforce contracts agreeing to the disposition of embryos after separation where one party no longer wants to be a parent because of the facts surrounding the creation of these agreements). 
be a parent." ${ }^{129}$ This exception was enforced in Reber v. Reiss, ${ }^{130}$ where the Superior Court of Pennsylvania found that Lynn Reiss's right to procreate outweighed her ex-husband, Howard Reber's, right not to procreate where it was almost certainly her only chance to be a biological parent and likely her only chance to be a parent at all given her health history. Reiss delayed treatment for breast cancer for several weeks after diagnosis to undergo IVF and create embryos with Reber, knowing that cancer treatments would substantially impede her fertility. The parties subsequently divorced. Reiss sought to implant the embryos over Reber's objection, and, with no previous agreement as to disposition of the embryos in the event of divorce, the court awarded the embryos to Reiss. The court stated that "unless and until our legislatures decide to tackle this issue, our courts must consider the individual circumstances of each case."131

In another, well-publicized battle, ${ }^{132}$ the Appellate Court of Illinois awarded custody of embryos to Karla Dunston over the objections of her

129. Purvis, supra note 121 , at 331 ("[I]ndeterminacy allows for the relative importance of male and female expectational parental interests to play a greater role in the court's analysis."); see Szafranski v. Duston, 993 N.E.2d 502, 515 (III.App. 1 Dist. 2013) ("Courts applying the balancing approach have noted that a party's inability to have a child weighs in his or her favor." (citation omitted)); J.B. v. M.B., 783 A.2d 707, 716 (N.J. 2001) (holding that ordinarily the right not to procreate should trump the right to procreate and denying husband custody of embryos for donation where he remained fertile with the caveat that the court reached no conclusion on the outcome where "a party who has become infertile seeks use of stored pre-embryos against the wishes of his or her partner"); Davis v. Davis, 842 S.W.2d 588, 604 (Tenn. 1992) (finding that husband's interests in avoiding procreation outweighed wife's interest in donating embryos after her remarriage following divorce but stating in dicta that "[t]he case would be closer if Mary Sue Davis were seeking to use the pre-embryos herself, but only if she could not achieve parenthood by any other reasonable means"); I. Glenn Cohen, The Right Not to Be a Genetic Parent?, 81 S. CAL. L. ReV. 1115, 1193 (2008) [hereinafter Cohen II] ("While it seems that the interest in avoiding unwanted genetic parenthood is greater than the general interest in access to particular genetic material, one might think that the balance between the interests is different when not having access to the pre[-]embryos makes it impossible to have any genetic children at all."); cf. A.Z. v. B.Z., 725 N.E.2d 1051 (Mass. 2000) (refusing to enforce agreement allowing wife to implant embryos after separation where couple already had two children).

130. Reber v. Reiss, 42 A.3d 1131 (Pa. Super. 2012).

131. Id. at 1142 (overruling husband's objections where wife promised not to seek child support and agreed to allow husband to be as involved as he wanted in the child's life and striking down his argument that he never intended to procreate with his wife given the nature of IVF).

132. See, e.g., Kim Bellware, Her Last Chance For a Baby. His Fight Against Forced Fatherhood. The Court Must Decide., Huffington Post (Jan. 26, 2015), http://www.huffingtonpost.com/2015/01/22/illinois-frozenembryo_n_6348920.html; Angie Leventis Lourgo \& Bonnie Miller Rubin, Court Gives Frozen Embryos to Chicago Woman Over Ex-Boyfriend's Objection, CHI. TRIB. (June 12, 2015), http://www.chicagotribune.com/news/local/breaking/ctembryos-court-ruling-met-20150612-story.html; Madeleine Schwartz, Who Owns 
ex-boyfriend, Jacob Szafranski. ${ }^{133}$ In the first appeal in the case, ${ }^{134}$ the court found, after reviewing precedent, that embryos in dispute should be disposed of (1) according to any ex ante agreement of the parties or (2) by weighing the parties' interests in the absence of an agreement. After the lower court on remand awarded the embryos to Dunston, the appellate court affirmed.

Dunston and Szafranski had been dating for a few months, and neither "expected their relationship to result in marriage" when Dunston was diagnosed with non-Hodgkin's lymphoma. ${ }^{135}$ At that time, Dunston delayed treatment to undergo IVF and Szafranski agreed to donate sperm to create embryos instead of having her use donor sperm. Although the couple signed an informed consent agreement, the agreement did not provide for disposition in the event that the couple separated and indicated only that the fertility clinic would adhere to any separate agreement of the parties. ${ }^{136}$ The parties visited a lawyer and discussed both co-parenting and sperm donation contracts but never executed an agreement. ${ }^{137}$ After the couple broke up, Szafranski confirmed in an email that the choice of using the embryos was Dunston's, but he subsequently changed his mind and demanded that she not use the embryos. ${ }^{138}$

Szafranski conceded that the parties reached an oral agreement prior to signing the fertility clinic's informed consent and creating the embryos. The court held that Szafranski intended at the time the contract was created to help Dunston produce embryos for the purpose of having her own biological children and the parties did not contemplate giving him a veto over the use of the embryos. ${ }^{139}$

The court also found that the application of a balancing test supported awarding the embryos to Dunston. Her last chance to have a biological child

Pre-Embryos?, NeW YORKER (Apr. 28, 2015), http://www.newyorker.com/tech/elements/who-owns-pre-embryos.

133. Szafranski v. Duston, 34 N.E.3d 1132, 1133 (III.App. 1 Dist. 2015), cert. denied, 136 S. Ct. 1230 (2016).

134. Szafranski v. Duston, 993 N.E.2d 502, 515 (III.App. 1 Dist. 2013) ("In addition to holding that agreements between the parties should be honored, we further hold that where there has been no advance agreement regarding the disposition of pre-embryos, 'then the relative interests of the parties in using or not using the pre-embryos must be weighed.' Although we acknowledge that this is not an ideal way to resolve a dispute implicating reproductive rights, we note that 'what is even worse ... is to give a possibly antagonized ex-spouse the power to either block parentage or to name the price that potential parentage will cost."' (citations omitted)).

135. Szafranksi, 34 N.E.3d at 1137.

136. Id. at 1138 .

137. Id. at 1139 .

138. Id. at 1141.

139. Id. at 1149 . 
outweighed his concerns over the stigma of conceiving a child in this manner. ${ }^{140}$ In weighing heavily Dunston's desire to have a biological child, the court "decline[d] to make a judicial determination that alternative methods of parenthood offer Karla an acceptable substitute to biological parenthood." 141

The exception made here to the general right not to procreate when balancing interests in embryo-custody disputes is easily analogous to disputes likely to arise as the prevalence of therapeutic PGD increases. In those cases, denying a parent with a gene for a genetic illness the chance to use embryos that have undergone PGD could result in: (1) that parent not being able to have a genetic child because of the risk of passing on the gene during natural conception, depending on age and resources to undergo further IVF and PGD to create more embryos; or (2) an increased risk that the parent seeking to use the embryos will conceive naturally and pass on the gene because of the desire to have a genetic child, again, depending on age and resources to undergo further procedures. In the first outcome, the balance is similar to the cases discussed above. The right to have a genetic child weighs heavily. In the second outcome, which assumes that the parent seeking to use the embryos has the alternative of natural conception, courts will have to weigh whether there is a right to have a healthy genetic child and whether that right outweighs another person's right not to procreate. Courts have weighed heavily the right to be a genetic parent, and this indicates that they will likely put a thumb on the scale again for the right to be a genetic parent of a healthy child. Yet, this runs the risk of giving those who use ARTs more rights than those who do not, since there is no right to a healthy child or right to be a healthy child.

Another question is how courts should weigh the interest of society in producing healthier children. If a parent with a gene for a genetic illness loses the chance to reproduce through therapeutic PGD and instead decides to conceive naturally in spite of the risk of passing on the gene, society will bear at least part of the cost of the child's illness through increased medical costs and decreased productivity as an adult. Should the courts be concerned with these social costs?

In The Right Not to Be a Genetic Parent?, Glenn Cohen argues that "many of these authorities have erred by conceiving of a monolithic right not to procreate, and we should instead recognize a bundle of rights having multiple possible sticks, consisting of a right not to be a gestational, legal, and genetic parent." ${ }^{142}$ Obviously, the right to be a gestational parent belongs only to a woman, while the other two sticks can belong to either

140. Id. at 1162 ("Karla testified that she was 'devastated' upon learning that she would lose her fertility and thought about how she wants to have a child 'with part of' her father, who passed away when she was five years old.").

141. Id. at 1163.

142. Cohen II, supra note 129 , at 1121 . 
men or women. ${ }^{143}$ Cohen asserts that the right not to be a genetic parent would be based on "unwanted 'attributional parenthood,' a harm that comes from the social assignment of the status of parent to the provider of genetic material that persist notwithstanding the fact that the legal system has declared him or her a nonparent." 144

To my point, Cohen questions whether society has distinct interests that should affect what law determines the outcome of these disputes. ${ }^{145}$ While he gives the example of what would happen if there were evidence that children born over one genetic parent's objection were "1000 times more likely to commit violent crimes compared to the population at large," ${ }^{146}$ my question here is what would happen if there were evidence that discarding the embryos-valuing the right not to be a genetic parent over the right to be a genetic parent-resulted in children born to the partner who sought genetic parenthood that were 1000 times more likely to have a serious genetic illness or chromosome abnormality. Cohen also questions how that balance changes if the person seeking to implant the embryos already has one or more genetic children. ${ }^{147}$

The tendency for courts to make an exception to the right not to procreate due to the importance of conceiving a genetic child results in an inference that the greater stakes in cases where a parent may otherwise conceive an unhealthy child will cause courts to increasingly favor the rights of those seeking to conceive through therapeutic PGD. Regardless of whether courts increasingly recognize the wrongful life tort, and I believe that they will, an emphasis on the rights of those who seek to conceive through therapeutic PGD inevitably stigmatizes the lives of those who are born with genes for genetic illnesses because their parents did not want to or could not afford to conceive using this procedure. In the next section, I argue that there is an administrative law solution to the disparity attributable to the high cost of PGD.

\section{Access for "Other Groups"}

Assuming it is not repealed, the ACA presents an opportunity to expand access to therapeutic PGD and other ARTs. The statute's goal of expanding access to health insurance and its antidiscrimination framework fit nicely with my arguments above about the need to expand access to reproductive

143. Id.

144. Id. at 1125.

145. Id. at 1133 ("That would give society a reason to oppose that pre[-]embryo's coming into being even if we assume that coming into being was in the pre[]embryo's best interest--although that reason might still be defeated, for example, by society's countervailing interest in protecting procreative autonomy.").

146. Id.

147. Id. at 1195. 
rights. These rights could also be incorporated under the essential health benefit provisions.

Scholars discussing the ACA's antidiscrimination provision have focused on whether it meets the challenge of providing a basic, equivalent level of health insurance to all, albeit within a two-track system of public and private benefits. ${ }^{148}$ As discussed further below, Jessica Roberts has focused on the need to shift from an antidiscrimination framework to a fundamental rights framework to decide which benefits are required to provide everyone with meaningful access to health insurance. ${ }^{149}$ She reserves the question of which benefits should be included on this list and who should decide. Here, I argue that ARTs such as IVF and PGD to screen out embryos with a genetic predisposition for illnesses that either result in early death or significantly impair quality of life should be included on that list of essential health benefits in spite of concerns about the overemphasis on genetic ties and the slippery slope to eugenics.

I argue that Section 1557 of the ACA should be considered a positive right in this situation to avoid the disparate impact that wealth has on healthcare access. The Secretary of Health and Human Services ("HHS"), now or in the next administration, should consider the desire of lowerincome individuals to produce healthy children when defining essential health benefits under the ACA. Although my proposed solution does not impact those covered by Medicaid, a subject for another article, it is a start at closing an important gap in our healthcare system and enforcing equal reproductive rights for all.

\section{A. A Positive Right under the ACA}

Statutory antidiscrimination provisions in health insurance demonstrate the tension between a private system that must rely on efficiency and focus on cost to profit and the desire of government to fairly care for all citizens. They suppress the use of traits to forecast policy losses by prohibiting insurance "carriers from relying on characteristics that are

148. See Sidney D. Watson, Section 1557 of the Affordable Care Act: Civil Rights, Health Reform, Race, and Equity, 55 How. L.J. 855, 857-58 (2012) ("Because the ACA continues the tradition of Medicaid for the poor and a variety of private insurance offerings for wealthier Americans, it has the potential to perpetuate America's dual track medical care with one system serving mostly white patients with private insurance and a different system for poorer, mostly minority patients with Medicaid. In fact, the ACA may exacerbate this two-tier system by creating a third tier of moderate-income Americans, half of whom are people of color, who obtain their health insurance through the new Exchanges using federal tax credit subsidies. By maintaining multiple sources of health insurance, the ACA may serve to reinforce and further segregate patients along racial lines.").

149. Jessica L. Roberts, "Healthism": A Critique of the Antidiscrimination Approach to Health Insurance and Health-Care Reform, 2012 U. ILL. L. REV. 1159, 1197 (2012). 
socially suspect, thus preventing insurers from exacerbating or trading on inequalities that exist outside of the insurance system." ${ }^{150}$

Fairness concerns dominate in the context of genetic discrimination. ${ }^{151}$ Adverse selection concerns are muted because the predisposition for a genetic illness typically involves a long time-horizon and a probability of acquiring the illness rather than a certainty (although dominant traits like the gene for Huntington's disease manifest one-hundred percent of the time when the gene is present). Most health insurers are concerned with short-term risks because participants may switch health insurance plans many times. ${ }^{152}$

As Wendy Mariner notes, however, "[c]ommercial health insurance policies occupy a somewhat unusual space among lines of insurance. They cross the boundary between conventional insurance and service contracts, because they cover both fortuitous losses, like accidental injuries and heart attacks, and predictable 'losses,' such as preventive services." ${ }^{153}$ The definition of preventive services is shifting with the growing wave of genetic selection and the future of genetic engineering. ${ }^{154}$ Whether a positive right to reproductive liberty is located in the Constitution, the ACA's antidiscrimination provision, or under the ACA's essential health benefits requirement is less important than recognizing that the model for health insurance is not changing with increasing coverage of ARTs-only the

150. Ronen Avraham, Kyle D. Logue \& Daniel Schwarcz, Towards a Universal Framework for Insurance Anti-Discrimination Laws, 21 ConN. INS. L.J. 1, 3 (2014-15) (examining how state insurance antidiscrimination laws generally balance "efficiency" and "fairness"); The article notes that employer-sponsored health insurance assuages the concern about adverse selection by spreading the risk and cost of caring for employees in poor health or with a "genetic predisposition to illness" among the larger, more diverse group. Id. at 28-29.

151. Id. at 32 ("Genetic discrimination in the context of health, life, and disability insurance immediately evokes Nazi Germany and its obsession with promoting the reproduction of more 'genetically desired' people and eliminating 'genetically defective' individuals. Under this worldview, Nazis first forced those with Huntington's disease to be sterilized and later murdered them in extermination facilities. The United States also has a history of forced sterilization based on supposed genetic defects." (citations omitted)).

152. Id. at 33. This is also one reason why health insurers are reluctant to fund expensive preventive care like therapeutic PGD to reduce or eliminate the risk of members acquiring genetic diseases. Although an insurer enrolls the parents before birth (when the costs for such treatment are incurred) and the child at birth, it is unlikely to continue to insure the child later on in life when the disease would manifest (and the cost savings from prevention are felt).

153. Wendy K. Mariner, The Picture Begins to Assert Itself: Rules of Construction for Essential Health Benefits in Health Insurance Plans Subject to the Affordable Care Act, 24 Annals Health L. 437, 451 (2015) (citations omitted).

154. See Tetsuya Ishii, Germ Line Genome Editing in Clinics: The Approaches, Objectives and Global Society, 16 BRIEFIngs Functional Genomics 1 (2015) (describing how a new technique called CRISPR that allows genome editing is being utilized in ARTS for prevention of diseases as well as genetic enhancement). 
definition of preventive care is. Because I think it unlikely that courts will find that failing to provide everyone with IVF and PGD is a violation of the rights to equal protection and substantive due process, I focus on the choice between the ACA's antidiscrimination provision and its essential health benefits requirement. The antidiscrimination provision is broad and permits discrimination against those with genetic illnesses by proxy, and I therefore argue that the Secretary should use statutory discretion to include therapeutic PGD among the EHBs.

\section{Antidiscrimination}

Section 1557 of the ACA states that individuals may not "be excluded from participating in, be denied the benefits of, or be subjected to discrimination under, any health program or activity" that receives federal funding-including credits and subsidies-or is administered by a government entity on the "grounds prohibited under title VI of the Civil Rights Act of 1964, title IX of the Education Amendments of 1972, the Age Discrimination Act of 1975, or section 794 of title 29."155 Those grounds include race, sex, age, and disability. ${ }^{156}$

The ACA's antidiscrimination provision regulates the content of insurance. And significantly, the ACA targets both intentional discrimination and de facto discrimination, or "facially neutral practices with a discriminatory impact." 157 The final rule provides specifically that the HHS Office of Civil Rights ("OCR") "interprets section 1557 as authorizing a private right of action for claims of disparate impact discrimination on the basis of any of the criteria enumerated in the legislation." 158 Although the OCR will adjudicate violations of section 1557 under Title VI of the Civil Rights Act, individuals can sue directly under section $1557 .{ }^{159}$

155. 42 U.S.C. $\S 18116(a)$ (2010) (citations omitted). The statute makes clear that this provision is not designed to limit or supersede the cited statutes. See 42 U.S.C. $\S 18116$ (b) (2010).

156. 42 U.S.C. § 2000 d (race, color, and national origin); 20 U.S.C. § 1681 (2012) (sex); 42 U.S.C. § 6101 (age); 29 U.S.C. § 794 (2014) (disability).

157. Mastroianni, supra note 7 , at 172.

158. Nondiscrimination in Health Programs and Activities, 81 Fed. Reg. 31376, 31440 (May 18, 2016) (to be codified at 45 C.F.R. pt. 92).

159. 45 C.F.R. § 92.301 (2016); see Rumble v. Fairview Health Servs., No. 14-cv-2037 (SRN/FLN), 2015 WL 1197415, at*11 (D. Minn. Mar. 16, 2015) ("[I]t appears Congress intended to create a new, health-specific, anti-discrimination cause of action that is subject to a singular standard, regardless of plaintiff's protected class status. Reading Section 1557 otherwise would lead to an illogical result, as different enforcement mechanisms and standards would apply to a Section 1557 plaintiff depending on whether plaintiff's claim is based on her race, sex, age, or disability. For instance, a plaintiff bringing a Section 1557 race discrimination claim could allege only disparate treatment, but plaintiffs bringing Section 1557 age, disability, or sex discrimination claims could allege disparate treatment or disparate impact." (footnote omitted) (citation omitted)); Timothy Jost, HHS 
The question remains whether courts will favor disparate impact claims under the ACA. ${ }^{160}$ Regardless, disparate impact litigation has a troubled history in Title VII employment discrimination claims and other areas of the law, and it is arguably inconsistent with equal protection under the Constitution. ${ }^{161}$ Thus, disparate impact litigation may not be the tool to protect a negative right to be free from affirmative-though unintentional-discrimination that it was previously considered, let alone a place to find a positive right to health insurance opportunities. ${ }^{162}$

The question of whether "programs that endeavor to remediate the harms done to a subordinated or disadvantaged class fundamentally differ from those that create or perpetuate subordination" and, therefore, do not violate equal protection, ${ }^{163}$ differs greatly in the context of health insurance. First, the costs of providing increased opportunities for equality among different races and for women are dispersed among a much larger number of people. In Ricci v. DeStefano, white and Hispanic firefighters ("Firefighters") brought suit against the city of New Haven, Connecticut ("City") under Title VII after the City refused to certify the results of a promotion examination due to a statistical disparity between white candidates' results minority candidates' results. ${ }^{164}$ The Firefighters claimed

Issues Health Equity Final Rule, HeAlth Aff. Blog (May 14, 2016), http://healthaffairs.org/blog/2016/05/14/hhs-issues-health-equity-final-rule/.

160. Govind Persad, Priority Setting, Cost-Effectiveness, and the Affordable Care Act, 41 AM. J.L. \& MED. 119, 160 (2015) (noting the recent trend of the Supreme Court to disfavor disparate impact claims under a variety of antidiscrimination statutes and querying whether the ACA will be treated similarly).

161. See Ricci v. DeStefano, 557 U.S. 557, 585 (2009) (holding that "before an employer can engage in intentional discrimination for the asserted purpose of avoiding or remedying an unintentional disparate impact, the employer must have a strong basis in evidence to believe it will be subject to disparate-impact liability if it fails to take the race-conscious, discriminatory action"); Samuel R. Bagenstos, The Structural Turn and the Limits of Antidiscrimination Law, 94 CAL. L. REV. 1, 20-24 (2006) (arguing for a structural approach, such as the disparate impact doctrine, to employment antidiscrimination law); Robert Belton, Title VII at Forty: A Brief Look at the Birth, Death, and Resurrection of the Disparate Impact Theory of Discrimination, 22 HOFSTRA LAB. \& EMP. L.J. 431, 454-63 (2005) (discussing how the disparate impact doctrine moved forward antidiscrimination law by making unintentional, as well as intentional, discrimination illegal and the history of difficulties that the disparate impact theory has faced); Michael Selmi, Was Disparate Impact Theory a Mistake?, 53 UCLA L. REV. 701, 732-45 (2006) (documenting the limitations of the disparate impact doctrine).

162. See, e.g., Cheryl I. Harris \& Kimberly West-Faulcon, Reading Ricci: Whitening Discrimination, Racing Test Fairness, 58 U.C.L.A. L. ReV. 73, 157-65 (2010); Cedric Merlin Powell, Harvesting New Conceptions of Equality: Opportunity, Results, and Neutrality, 31 St. LouIS U. PUB. L. ReV. 255, 259-61 (2012).

163. Lawrence Rosenthal, Saving Disparate Impact, 34 CARdozo L. Rev. 2157, 2205 (2013) (arguing that the disparate impact theory of liability and the Equal Protection Clause can, and should, be reconciled).

164. Ricci, 557 U.S. at 561-62. 
that refusal to certify the results constituted discrimination against them on the basis of their race. ${ }^{165}$ The City claimed that if they had certified the results they would have faced liability under Title VII "for adopting a practice having a disparate impact on minority firefighters." ${ }^{166}$ The Court held that an action such as the City's refusal to certify the results "is impermissible under Title VII unless the employer can demonstrate a strong basis in evidence that, had it not taken the action, it would have been liable under the disparate-impact statute." ${ }^{167}$ The Court found that the City could not meet that threshold standard and, therefore, had violated Title VII. ${ }^{168}$ In attempting to effectuate reproductive liberty, however, any increased costs for health insurance companies required to cover PGD could be offset by cost savings resulting from preventing genetic illnesses or short-term government subsidies, or by small general premium increases.

Second, except for perhaps a minimal increase in health insurance premiums, no one is harmed by providing additional health insurance opportunities to those with genes for genetic illnesses. No one loses insurance because of increasing coverage for therapeutic PGD any more than they lose coverage when an expensive new medication or medical procedure is covered under those plans. Even if the costs are greater than expected, and insurance companies must increase premiums or cut back in other ways to provide these benefits, this is the business of health insurance. No one would dare suggest that insurance companies not treat the genetic illnesses when they manifest because it is too costly. Why should coverage for preventive care be any different? ${ }^{169}$

Jessica Roberts asserts that the antidiscrimination framework adopted under the ACA is simply incompatible with a for-profit health insurance industry. The ACA, in spite of good intentions, still burdens the unhealthy by using health proxies instead of explicit considerations of health status. ${ }^{170}$ Roberts discusses how this "healthism" - or discrimination based on health status-becomes illicit discrimination under the ACA and other recent statutes prohibiting such discrimination. ${ }^{171}$ Antidiscrimination frameworks

165. Id. at 562 .

166. Id. at 563 .

167. Id.

168. Given the Court's holding, it did not reach the question of whether the City's action violated the Equal Protection Clause. Id.

169. Nondiscrimination in Health Programs and Activities, 81 Fed. Reg. at 31377 ("Covered entities should bear in mind the purposes of the ACA and Section 1557 - to expand access to care and coverage and eliminate barriers to access - in interpreting requirements of the final rule.").

170. Roberts, supra note 149 , at 1161-62.

171. Id. at 1171-72 ("If health status joins the catalogue of forbidden traits, health insurers are undoubtedly discriminators.... But what makes one kind of differentiation acceptable and another morally reprehensible--and perhaps legally actionable--is a complicated question and one that relies heavily on historical and cultural context. As one scholar has explained, 'Discrimination is not 
typically prevent decision makers from considering protected traits, forcing them into blindness and representing a negative right-the right to be free from differentiation due to a suspect categorization. ${ }^{172}$ An antidiscrimination framework transforms acceptable risk allocation and profit maximization by insurers into unacceptable discrimination. ${ }^{173}$ This occurs because the traditional methods the health insurance industry uses make insurance expensive or unavailable to those who need its services the most. ${ }^{174}$

The antidiscrimination frameworks of the Health Insurance Portability and Accountability Act ("HIPAA"), the Genetic Information Nondiscrimination Act ("GINA"), and the ACA fail to properly protect the unhealthy. HIPAA does not require that group health insurers offer any particular benefits or limit premiums, keeping insurance out of reach for the sick. ${ }^{175}$ Under GINA, Congress prohibited discrimination based on genetic information, in spite of adverse-selection issues, but the statute favors the healthy because it excludes "discrimination on the basis of a manifested genetic condition once it is diagnosable by other means." 176 Once a genetic condition results in symptoms that make the disease identifiable through means other than genetic testing, GINA offers no protection. ${ }^{177}$

The ACA prohibits several means of discriminating directly against the unhealthy but uses instead proxies that continue to favor the healthy. The

one thing, but many."' (footnotes omitted)). Some have compared denying health insurance to the sick to discrimination based on race. Id. at 1175-76 ("Putting health status on par with race constitutes an important rhetorical move, as race is widely regarded as the most invidious basis for discrimination." (footnote omitted)).

172. See id. at 1178.

173. Id. at 1165 ("Profitable insurance thus relies on accurate, calculable risks .... As a result, health insurers have historically employed medical information, in addition to demographic and behavioral factors like sex, age, and smoking, when determining coverage and setting premiums." (footnotes omitted)).

174. Id. at 1167.

175. Id. at 1182 ("While group health insurers cannot discriminate against individuals in the group, they can still make group-wide decisions based on health status, such as the kind of benefits or coverage to provide or the amount of a premium to impose. Thus, if one member of a group develops a serious illness, it can affect the health insurance of all group members." (footnote omitted)).

176. Id. at 1184 ("GINA defines 'genetic information' as the results of an individual's genetic tests, the results of an individual's family members' genetic tests, and the manifestation of a disease or disorder in an individual's family." (footnote omitted)).

177. Id. at 1185 ("Consequently, the statute does not protect the results of a test that detects a manifested condition--even if that condition has a genetic basis. Thus, a test that diagnoses Huntington's disease, a genetically based disorder with a onehundred percent correlation between the genetic variant and the condition, is not a 'genetic test' for insurance discrimination purposes." (footnote omitted)). 
statute prohibits pre-existing condition exclusions. ${ }^{178}$ It prevents insurers from discriminating in setting premiums for the individual and small-group markets, but it permits insurance companies to consider family size, geographic location, age, and tobacco use. ${ }^{179}$ And although the ACA prohibits discrimination based on health status, it allows premiums for employer-provided plans to fluctuate by up to thirty percent if an employee completes a wellness program. ${ }^{180}$

The use of proxies to determine premiums particularly disadvantages the poor. Considering where a person lives results in harm to the urban and rural poor because they have more health problems and fewer health facilities. Community rating-requiring insurers to charge the same premiums for all health policies sold within a particular area-could harm these groups depending on how the boundaries are drawn. ${ }^{181}$ Similarly, since those with lower incomes use tobacco at higher rates, increasing premiums based on tobacco use hurts those with lower socioeconomic status. ${ }^{182}$ Congress made trade-offs to continue the private system of health insurance that exists alongside our public benefits. A continuation of private health insurance requires insurers to keep costs down by increasing costs for high-risk participants, now that they cannot be excluded from coverage entirely under the ACA's pre-existing condition and lifetime maximum coverage limitations. ${ }^{183}$

Roberts suggests a shift from an antidiscrimination framework to a fundamental rights framework that bridges equal protection and substantive due process. ${ }^{184}$ The focus shifts from discrimination based on

178. Id. at 1187.

179. Id. at 1188 ("While individual-and small-group insurers may no longer explicitly use past or current health status in determining premiums, they may still vary their rates based on these four factors, which may, in fact, serve as crude proxies for health status." (footnote omitted)).

180. Id. at 1188-90 ("Although the law is not 'healthist' on its face, it still favors the same individuals who benefited under the preceding system. Within the individual and small-group markets, the new rating criteria act as proxies for health and may, therefore, perpetuate existing disparities. Within the large-group market, wellness programs could likewise adversely affect the sick, who may be unable to participate equitably.... Although the law succeeds from an antidifferentiation standpoint, it fails by producing discriminatory outcomes . . . . To borrow language from Title VII doctrine, the new policies will likely have a 'disparate impact' on the basis of health-related factors." (footnotes omitted)).

181. Id. at 1192 ("Importantly, under the new system, an income-based subsidy will be available to help offset the cost of health insurance, yet particular lower-income populations might still experience disadvantage--most notably the 'near poor."').

182. Id. at 1193.

183. Id. at 1164 .

184. Id. at 1197-98 ('[Kenji Yoshino] explains that a growing 'pluralism anxiety' has pushed the Supreme Court to move away from acknowledging equality concerns framed as group-based identity claims in favor of those presented in terms of the more expansive doctrines of liberty and universally held fundamental rights. Thus, 
health status to the lack of "sufficient health-insurance coverage for all people." 185 The next step is figuring out what health benefits are required under this right to health insurance and who should decide what benefits need to be included. ${ }^{186}$ The discussion moves from who to cover to what services to cover, which is precisely what the ACA's EHB provisions require.

The reason that I argue the ACA's antidiscrimination provision is not the place to locate a positive right to ARTs is because there is "no logical stopping point." ${ }^{187}$ Remediating all differential outcomes in utilization of health services, which is what a robust disparate-impact jurisprudence under the ACA would require, would take more resources than the current health insurance system can offer. ${ }^{188}$ And few would argue that this was the intent of the ACA, particularly without greater congressional funding attached.

\section{Essential Health Benefits}

Forcing health insurers to cover the cost of IVF and PGD to deselect embryos with genes for grave genetic illnesses because it is an essential health benefit is compatible with the practices of private insurers. First, depending on which genes are included on the list, the percentage of the population affected is small, particularly since some will choose not to undergo the procedure when having children, even if it is free. ${ }^{189}$ Second, insurers will see cost savings because of the reduction in the manifestation of these genetic illnesses in later years. The reason insurers have not

substantive due process claims--situated in a rights-based frame--may encompass concerns related to inequality and group subordination." (footnotes omitted)).

185. Id. at 1198.

186. Id. at 1199 ("The answers to these questions are never simple. Creating a baseline for health insurance inevitably excludes certain kinds of coverage, thereby leaving some individuals with less than optimal access to health care.").

187. Rosenthal, supra note 163 , at 2208 ("To avoid the demands of strict scrutiny, one might instead conclude that any preference favoring women or minorities is constitutionally unobjectionable, but a jurisprudence willing to uphold any kind of racial preference favoring minority groups has no logical stopping point--precisely the reason the Court has rejected preferences designed to remediate societal discrimination." (footnote omitted)).

188. As Sidney Watson writes, "Broad statements prohibiting facially neutral policies and practices that have an unjustified disparate racial impact do not give health insurers, health care providers, the agency, or courts sufficient guidance on how to strike the proper balance between equity concerns and economic and profit motives." Watson, supra note 148 , at 860.

189. See About Cystic Fibrosis, CYstic Fibrosis Found., https://www.cff.org/What-isCF/About-Cystic-Fibrosis/ (last visited July 26, 2016) (estimating that .0001\% of the U.S. population is afflicted with Huntington's disease and $.00009 \%$ is afflicted with Cystic Fibrosis); Stephanie Liou, Population Genetics and Huntington's Disease, Huntington's Outreach Project Educ. Stan. (Oct. 26, 2010), http://web.stanford.edu/group/hopes/cgi-bin/hopes_test/population-geneticsand-hd/\#the-frequency-of-hd. 
implemented coverage already, given the cost savings, is that they may never see those cost savings. If insurers spend money on therapeutic PGD and produce a child without genetic illness, the child may be covered by a different insurer when the cost savings are realized. Yet if all insurers are required to cover therapeutic PGD, they will all see the cost savings later, even if the children selected through PGD that they paid for are not the healthy children or adults they later cover and see the cost savings from. The ACA thus presents a collective action fix to an insurance problem.

The ACA requires health insurance plans to cover, without cost sharing, preventive health services, and it specifically provides for such care and screenings for women and children. ${ }^{190}$ The statute states:

A group health plan and a health insurance issuer offering group or individual health insurance coverage shall, at a minimum, provide coverage for and shall not impose any cost sharing requirements for-

(1) evidence-based items or services that have in effect a rating of " $A$ " or " $B$ " in the current recommendations of the United States Preventive Services Task Force; ... .

(3) with respect to infants, children, and adolescents, evidenceinformed preventive care and screenings provided for in the comprehensive guidelines supported by the Health Resources and Services Administration.

(4) with respect to women, such additional preventive care and screenings not described in paragraph (1) as provided for in comprehensive guidelines supported by the Health Resources and Services Administration for purposes of this paragraph. ${ }^{191}$

The statute also prohibits annual or lifetime limits on per-beneficiary health benefits by an insurance plan for any "essential health benefits under section 18022 (b) of this title." ${ }^{192}$ The Secretary has discretion to

190. 42 U.S.C. $\S 300$ gg-13(a)(2)-(3) (2012); This provision of the ACA has been the subject of recent litigation in which the mandates for preventative services in the form of contraceptives created under the provision were challenged as violating religious freedom. See Burwell v. Hobby Lobby Stores, Inc., 134 S. Ct. 2751 (2014) (upholding an as-applied challenge to the contraceptive mandate as substantially burdening the exercise of religion of the companies forced to provide health insurance coverage for such services).

191. 42 U.S.C. § 300gg-13(a)(1)-(4) (footnote omitted).

192. 42 U.S.C. § 300gg-11 (“(a) Prohibition (1) In general - A group health plan and a health insurance offering group or individual health insurance coverage may not establish--(A) lifetime limits on the dollar value of benefits for any participant or beneficiary; or (B) except as provided in paragraph (2), annual limits on the dollar value of benefits for any participant or beneficiary . . . . (b) Per beneficiary limits Subsection (a) shall not be construed to prevent a group health plan or health insurance coverage from placing annual or lifetime per beneficiary limits on specific covered benefits that are not essential health benefits under section 
define "essential health benefits" with a few limitations. ${ }^{193}$ Essential health benefits must include, among other enumerated items, maternity and newborn care and preventive and wellness services. ${ }^{194}$ In addition, essential health benefits must be "equal to the scope of benefits provided under a typical employer plan, as determined by the Secretary." ${ }^{195}$ Yet, among other "[r]equired elements for consideration" when defining essential health benefits, "the Secretary shall ... (C) take into account the health care needs of diverse segments of the population, including women, children, persons with disabilities, and other groups." 196

My argument here is that there is room for an administrative-law solution to the socioeconomic and moral quandary I presented above with the Baker and Smith families. The ACA's focus on providing preventive health services, particularly for women and children, which includes classifying them as essential health benefits not subject to per-beneficiary annual or lifetime limits, allows the Secretary to include IVF and PGD to screen out genetic diseases among such preventive health services for women and children. In addition, the requirement that the Secretary consider the "health care needs of diverse segments of the population, including ... other groups" 197 is an avenue for regulations that consider the health needs of the poor, which-though admittedly including many other urgent needs-surely includes the need not to pass preventable genetic diseases to their children. ${ }^{198}$

18022(b) of this title, to the extent that such limits are otherwise permitted under Federal or State law.").

193. 42 U.S.C. § $18022(b)(1)$.

194. 42 U.S.C. § 18022(b)(1)(D), (I).

195. 42 U.S.C. $\S 18022(b)(2)(A)$ ("The Secretary shall ensure that the scope of the essential health benefits under paragraph (1) is equal to the scope of benefits provided under a typical employer plan, as determined by the Secretary. To inform this determination, the Secretary of Labor shall conduct a survey of employersponsored coverage to determine the benefits typically covered by employers, including multiemployer plans, and provide a report on such survey to the Secretary.").

196. 42 U.S.C. § $18022(b)(4)$.

197. 42 U.S.C. § $18022($ b) (4)(C).

198. See Jason Potter Burda, When Condoms Fail: Making Room under the ACA Blanket for PrEP HIV Prevention, 52 SAN DIEGO L. REv. 171, 227 (2015) (arguing that HHS should require health plan administrators to consider the needs of subpopulations at high risk for HIV, such as men who have sex with men, by covering PrEP (oral HIV pre-exposure prophylactic medication)); Daar I, supra note 8, at 265 ("[T]he current limited access to PGD should be addressed not by denying the available technology to the few who can afford it, but by ensuring wider access for all. Concern for the genetic health of one's children is not a value limited to parents with resources; it is a universal value that can only be fully realized in a society that devotes its scarce resources to providing the most up to date technologies to everyone."); Sarah E. Gage, Note, The Transgender Eligibility Gap: How the ACA Fails to Cover Medically Necessary Treatment for Transgender Individuals and How HHS Can Fix It, 49 New ENG. L. Rev. 499, 511-13 (2015) (arguing that section 
This provision, section $18022(b)(4)(C)$, requiring that the Secretary decide EHBs by looking in part to the needs of diverse subpopulations, means that insurance carriers' calculations cannot simply include the most cost-effective benefits or those that have the largest benefit to the population overall because "appropriately considering the needs of subgroups requires deviating from the strict pursuit of total benefit." ${ }^{199} \mathrm{~A}$ key question moving forward is "which 'diverse segments' are relevant." 200

The ACA does not address infertility treatment coverage, nor do any subsequent HHS regulations under the statute. HHS allows states to incorporate their own EHB standards into the insurance plans they regulate, and fifteen states mandate some amount of coverage for infertility treatments. ${ }^{201}$ While some studies have shown that requiring private insurance to cover fertility treatments does not increase the use of those treatments significantly, ${ }^{202}$ this is likely because the population covered by private insurance (particularly pre-ACA) is wealthier and already has access to ARTs. This evidence shows that demand is being suppressed by the high cost of ARTs for those without insurance coverage.

Many will be concerned with the government mandating coverage for fertility treatments. I therefore move next to addressing the implications of mandating such coverage for therapeutic PGD and, importantly, the implications if we do not adopt such coverage.

\section{B. Lack of Access as Eugenics}

My argument in this article is subject to three main, not unrelated, critiques: (1) many or most of those who cannot afford PGD, and ARTs more broadly, do not want access, and requiring access through health insurance will coerce them into utilizing the procedures, (2) providing access to PGD

$18022(\mathrm{~b})(4)(\mathrm{C})$ of the ACA is an avenue to increase gender-confirming care for transgender people, although other provisions harm this effort).

199. Persad, supra note 160 , at 147 ; Id. at 166 (The ACA's provisions "are potentially dangerous: to the extent that they promote a view that considerations of cost and effectiveness are completely outweighed by the gain of even a moment of life, they threaten the possibility of achieving the healthcare system we need--one that supports public health while reining in rising costs .... Taking seriously the challenge that the ACA's provisions pose requires a health care system that does justice to the complexity of our values.").

200. Id. at 147 ("[F]actors... such as race, color, national origin, gender, gender identify, and sexual orientation, are somewhat less likely to produce debate" than factors "clearly relevant to medical practice, such as age and disability." (footnote omitted)).

201. Mastroianni, supra note 7, at 153-54 ("Specifically, [ ]HHS proposed a policy in December 2011 that provided states with 'the flexibility to select . . . benchmark plan[s]' based upon typical insurance coverage plans within the state. On February 27, 2015, [ ]HHS renewed this policy through 2017." (second and third alterations in original) (footnotes omitted)).

202. Judith F. Daar, Accessing Reproductive Technologies: Invisible Barriers, Indelible Harms, 23 BeRKELEY J. GendeR L. \& JUST. 18, 37 (2008) [hereinafter Daar III]. 
for one illness or trait creates pressure to provide access to PGD for another illness or trait, and providing access to one ART creates pressure to provide access to another ART, in an endless line-drawing exercise, and (3) increasing access to and use of therapeutic PGD will stigmatize those with disabilities or illnesses in society. None of these concerns outweigh the growing reality that lack of access to PGD and ARTs generally is becoming a form of reverse eugenics in this country, or the "new eugenics" as Judith Daar calls it in her recent book, ${ }^{203}$ but I explore each in detail below before asserting that these critiques are allowing an invidious model of eugenics to take hold.

Dorothy Roberts argues that maintaining genetic ties is a focus of whites, while government policies discourage black women from having children. ${ }^{204}$ If genetic ties are important mainly to whites, is it racist to encourage or coerce the genetic tie in minorities through subsidies? In the face of a grave, genetic illness, there is the choice to test and abort any affected fetus, to adopt children, to use a sperm or egg donor, or to not have children at all. Why choose this policy of subsidized assisted reproductive technology?

My answer once again comes back to choice. First, we have no accurate way of knowing what the poor, including minorities, want in this situation because they have no access and, therefore, no real choice. ${ }^{205}$ Racial bias

203. Daar II, supra note 77. Daar argues that "the true eugenic effect of ART is not in its use but in its deprivation." Id. at 192. She compares the effects of numerous economic and social barriers to ART to historical eugenic policies that prevented supposed undesirables from reproducing and concludes that the impact is similar because both the old and new forms of eugenics "depriv[e] them [of] the opportunity to reproduce in unison with more favored populations." Id.

204. Roberts I, supra note 1, at 944 ("The monumental effort, expense and technological invention that goes into the new reproduction marks the children produced as especially valuable. It proclaims the unmistakable message that white children are precious enough to devote billions of dollars towards their creation. Black children, on the other hand, are the primary object of welfare reform measures designed to discourage poor women from procreation."); Roberts III, supra note 85 , at 213 ("At a time when wealthy white women have access to technologies designed to produce genetically screened babies, an assortment of laws and policies discourage women of color from having babies at all."). But see Janet L. Dolgin, Biological Evaluations: Blood, Genes, and Family, 41 AKRON L. ReV. 347, 364 (2008) (arguing that as "nontraditional families-of-choice" have proliferated, genetic ties have become "an essential component of personal and group identity" (footnote omitted)). The possibility remains, then, that genetic ties are increasingly prevalent as a way to bind nontraditional families. Genetic ties may be more of a focus for whites in that case simply because minorities lack access to assisted reproduction. It is possible that Roberts has the flow of causation wrong, and increased use of ARTs is not a result of the importance of genetic ties to whites but instead a result of the increasing number of nontraditional families who increasingly value those ties.

205. See Daar III, supra note 202, at 38-43 (discussing higher rates of infertility among minorities but lower rates of treatment due to lower socioeconomic status and correspondingly lower rates of health insurance and higher rates of physician bias and distrust of the healthcare system). Although research has focused on gaps in 
operates both explicitly and implicitly in healthcare to affect the diagnoses and treatments minorities receive. As Ruqaiijah Yearby writes, "The largest disparity in accessing quality health care and health status in the United States remains between African-Americans and Caucasians." ${ }^{206}$ It is difficult to gauge the preferences of racial minorities who have a gene for a serious illness and cannot afford PGD without giving them access. While it is possible that some will then use the procedure out of a sense that society demands they produce "healthy" children and they will be ostracized if they do otherwise, it is more coercive to deny access to a choice than to subsidize it. 207

Viewing funding for PGD as coercive requires an assumption that the baseline is a lack of funding for assisted reproduction and an unequal distribution of wealth within society. ${ }^{208}$ If, instead, the unequal distribution of resources is conceived of as a result of laws that concentrate wealth among a small percentage of the population and particularly disadvantage

the utilization rates of fertility treatments between whites and minorities, without equal funding, it is pure speculation to assume that their interest level differs.

206. Yearby, supra note 6, at 1285-87 (footnote omitted) (“Racial bias in health care operates on three different levels: interpersonal, institutional, and structural. Interpersonal bias is the conscious (explicit) and/or unconscious (implicit) use of prejudice in interactions between individuals. [Gives example of doctors making different treatment decisions that result in higher mortality rates for AfricanAmericans than Caucasians.]... Institutional bias operates through organizational structures within institutions, which 'establish separate and independent barriers' to health care services. [Gives example of hospital closures in African-American communities.] ... Finally, operating at a societal level, structural bias exists in the organizational structure of society, which 'privile[ges] some groups... [while] denying others access to the resources of society,' including health care. [Gives example of health care based on ability to pay instead of needs of patients.]" (fifth, sixth, and seventh alterations in original) (footnotes omitted)).

207. But see Roberts III, supra note 85, at 221 ("Making citizens responsible for managing their health at the genetic level reflects the shift of responsibility for public welfare from the state to the private realms of market and family.... Today, state genetic testing programs do not force citizens to participate. Instead the government and corporate sectors rely on the sense of obligation individuals feel to control their own health at the genetic level. Turning people into 'gene carriers' concentrates responsibility on them to manage their own genetic predispositions, shifting the spotlight away from state responsibility for ensuring healthy living conditions.").

208. See Sunstein, supra note 51, at 895 ("[T] he existing distribution is not natural and does not provide a neutral baseline; it resulted in part from government decisions; efforts to improve the lot of the disadvantaged fall comfortably within the police power, should not be treated as impermissibly partisan, and may even be constitutionally compelled, especially where there is racial discrimination on the face of a statute."). 
minorities, then funding is merely an effort to get us back to the baseline of equality and remove the coercive effects of such maldistribution. ${ }^{209}$

It is, of course, possible that increased public funding will not result in increased use of therapeutic PGD by the poor and minorities who currently use ART in far lower numbers than wealthy whites, even if they can afford the procedures. ${ }^{210}$ There is no doubt, however, that public funding is necessary to overcome financial and social barriers to equal access to this treatment. As Dorothy Roberts writes, "It is hard to imagine a multimillion dollar industry designed to create Black children."211 The government, therefore, has a responsibility to ensure that society does not entrust the creation of healthier children to private industry.

The second critique, related to the first, argues that because covering therapeutic PGD essentially requires drawing lines between acceptable and unacceptable uses of PGD and favored or subsidized ARTs and disfavored ARTs, no line should be drawn at all, no subsidies should be given, or all use of the technology should be prohibited. This critique is informed by the question of where to draw the line for the negative right to be free from interference with reproductive liberty. Samuel Bagenstos writes that "we confront a classic Legal Realist baseline problem: all choices are made under an array of constraints, so the government will always have some plausible argument for regulating to promote choice. And the notion of autonomy, by itself, will not provide a basis for rejecting any such regulation." ${ }^{212} \mathrm{He}$ concludes that the normative question is: "What kinds of (publicly or privately imposed) constraints are we going to treat as rendering a choice unfree)?" 213 Subsidizing certain uses of PGD and certain ARTs overall will inevitably favor those now free choices. Society must weigh which traits it is ethically and financially appropriate to subsidize deselecting. Lines are always being drawn in health insurance coverage.

On the last critique, disability rights advocates have joined pro-life activists in their opposition to expanding access to therapeutic PGD out of fear that it would stigmatize those with disabilities or illnesses in society. They argue that the practice incorporates "discriminatory attitudes about disability, and that any 'choice' will not be a free one in light of social

209. Id. at 917-18 (discussing Lochner era's continuing effect on common law because it assumes that the "current distribution of benefits and burdens along racial lines is simply 'there'").

210. Roberts II, supra note 9, at 245 ("Yet there is a stark racial disparity in the use of new reproductive technologies that seems to result from a complex interplay of financial barriers, physician referrals, and cultural preferences.").

211. Id. at 246.

212. Bagenstos I, supra note 79, at 442 (footnotes omitted) (discussing position of disability rights advocates on abortion regulation).

213. Id. at 451-52 (acknowledging that financial constraints may effectively prevent a poor woman from exercising her right to an abortion but stating that "[i]n a capitalist society... the government has no general affirmative obligation to provide for its citizens" (footnote omitted)). 
pressures" including physician bias and social stigma. ${ }^{214}$ While those who are not disabled often believe that the disabled lead a tortured and abnormal existence, most of the disabled do not view their lives that way, or would not in the absence of the social stigma. ${ }^{215}$

Disability rights activists have spoken out frequently against the use of genetic testing to selectively abort fetuses with genetic mutations that result in illness or disability. Their concern is the fulfillment of "the eugenicist's dream of eliminating disabilities by eliminating people with disabilities." 216 If the number of disabled people decreases, their voice and push against discrimination is reduced, and it becomes easier to continuously isolate them and reduce their numbers further in society. ${ }^{217}$

I share the concern that deselecting embryos (in the case of PGD) with a gene that results in a high likelihood of disability at birth or later in life will stigmatize the disabled and is the product of incomplete information and physician bias at times. Yet, if we assume that the wealthy will continue to use this procedure for this purpose (a likely assumption), failing to subsidize PGD for the poor results in a disabled population that is stigmatized by society's views on both disability and poverty. It seems more likely to me that prejudice against the disabled will grow as the wealthy opt out and the disabled population is increasingly poor. If poor parents want to opt out as well, it should not be acceptable for society to place the weight of the moral quandary inherent in deselecting for disabilities on their shoulders. The argument that we should not subsidize therapeutic PGD because it will stigmatize the disabled is only valid if we prohibit the use of PGD for everyone. ${ }^{218}$

Historically, "[e]ugenicists believed that most social problems were caused by hereditary faults of those afflicted by the problem, and they eventually sought to eliminate these societal problems through selective

214. Id. at 428-37 (discussing disability rights critique in the examples of withholding treatment from infants with disabilities and assisted suicide).

215. Id. at 435-37 ("Disability rights advocates have long argued that the proper remedy for such stigmatization is not medical treatment to eliminate disabilities-and certainly not medical interventions to eliminate people with disabilities--but is instead guarantees of civil rights to change the hostile and inaccessible aspects of society." (footnote omitted)). This argues in favor of education as part of true reproductive liberty instead of banning PGD; But see Vuko Andrić \& Joachim Wündisch, Is It Bad to be Disabled? Adjudicating Between the Mere-Difference and the Bad-Difference Views of Disability, 9 J. ETHICs \& Soc. PHIL. 1, 1 (2015).

216. Bagenstos I, supra note 79, at 439 (footnote omitted).

217. Id. at $439-41$ (noting that the prescription of many disability rights advocates is not the elimination of abortion, however, but requiring physicians to provide unbiased information about the lives of the disabled and their value to those seeking to abort fetuses with genetic abnormalities).

218. Perhaps some balance is found in comparing my argument here in favor of the use of therapeutic PGD in a way that will arguably stigmatize the disabled with Jessica Roberts's view that the ACA is a civil rights law for the disabled. See Jessica L. Roberts, Health Law as Disability Rights Law, 97 MinN. L. REV. 1963, 1964 (2013). 
breeding." 219 Therapeutic PGD and other ARTs targeted to screen out genetic disease and chromosome abnormalities target narrow illnesses and conditions and seek to eliminate them. Instead of blaming more complex social problems on genetics, the technology seeks to blame Huntington's disease (for example) on the gene that produces the disease and eliminate its manifestation in the population. The question is not only whether it means a return to our eugenic past to engage in this practice and seek to eliminate disabilities, ${ }^{220}$ but also what it means to eliminate bad genes only in the wealthy, white population this time. We have given rise to a movement for reverse eugenics.

Judith Daar writes about the practical "barriers" that create a "modernday eugenics," including cost and race. ${ }^{221}$ She argues that:

[s]o long as ART remains a private good that, without legal consequence, is withheld from the least well-off among us, birth by assisted conception will take on a eugenic quality - one that rivals the goals of the earlier movement to repress breeding by those deemed unworthy of dynastic participation in the human race. ${ }^{222}$

I assert here that lack of access is oppressive and needs to be viewed as an affirmative harm.

The failure to find a positive right to this technology is allowing current income inequality to grow in a way that many feel uncomfortable discussing because of its ableist origins. If we cannot prohibit wealthy whites from using this technology or decide that we should not do so because of the good that the technology achieves or the importance of reproductive choice, then the poor-including a disproportionate share of minoritieswill be made to bear the cost of caring for those with genetic illnesses or chromosome abnormalities.

219. Daar III, supra note 202, at 78-80 (discussing terrible "legacy of state control over procreation" through forced sterilization and its impact on ART).

220. See, e.g., Mary B. Mahowald, Aren't We All Eugenicists?: Commentary on Paul Lombardo's "Taking Eugenics Seriously", 30 FlA. St. U. L. ReV. 219, 220 (2003); Michael J. Malinowski, Choosing the Genetic Makeup of Children: Our Eugenics Past-Present, and Future?, 36 ConN. L. ReV. 125, 130 (2003); Michelle Oberman, Thirteen Ways of Looking at Buck v. Bell: Thoughts Occasioned by Paul Lombardo's Three Generations, No Imbeciles, 59 J. Legal Educ. 357, 358 (2010).

221. Daar III, supra note 202, at 81 ("But isn't the deprivation of reproductive opportunity just as coercive as any formal, explicit directive to forgo offspring? .. . The coercive eugenic nature of ART barriers comes into sharp focus upon inspection of the individuals whose access to assisted conception is most suppressed--poor, minority, unmarried individuals who historically lack political and economic power. These are the very persons, who like their early twentieth century counterparts, are not terribly welcome in a society that measures human improvement by its ability to coalesce around a set of homogeneous characteristics.").

222. Id.; see Daar II, supra note 77, at xiv ("This exercise of procreative deprivation is eugenic to the core."). 


\section{Conclusion}

Unequal access to healthcare is nothing new. ${ }^{223}$ However, economic inequality has, in recent months, moved up on our country's list of priorities. With that change comes new openings for combatting inequality in access to healthcare. The next step is to fix the access problem in ART, with the most immediate need in the area of therapeutic PGD. ${ }^{224}$ The time has come for health-law scholars and courts to declare that there is no liberty in reproductive rights without equal access.

223. MehLMAN \& BotKIN, supra note 24, at 61-62 (“An examination of our health care system shows that, regardless of how unpopular it may be to give people preferences on the basis of their social status, we are willing to tolerate a significant degree of unequal access to health care based on wealth.").

224. Daar I, supra note 9, at 271-72 ("For parents who use PGD to avoid passing a deleterious genetic disorder to a child, their quest is not one for perfection, but rather for normalcy within health parameters. Choosing not to birth children with serious illnesses seems consistent with natural parental instincts to protect offspring from pain and suffering. To view the use of PGD for medical selection as a desire to enhance our children beyond that which human nature currently contemplates is to suggest that parents who seek cures for their ailing children wrongfully challenge the natural order of life. If we cannot imagine denying parents the right to seek cures and therapies for their ailing children, why should we imagine a system for denying parents the right to ensure the health of their children before they are born?"). 